\title{
Insulin Receptor in Aplysia Neurons: Characterization, Molecular Cloning, and Modulation of lon Currents
}

\author{
Elizabeth A. Jonas, ${ }^{2, a}$ Ronald J. Knox, ${ }^{2}$ Leonard K. Kaczmarek, ${ }^{2}$ James H. Schwartz, ${ }^{1}$ \\ and David H. Solomon ${ }^{1, \mathrm{a}}$ \\ ${ }^{1}$ Center for Neurobiology and Behavior, Columbia University College of Physicians and Surgeons, New York, New York \\ 10032, and 2Department of Pharmacology, Yale University School of Medicine, New Haven, Connecticut 06520
}

\begin{abstract}
We have isolated the cDNA for a tyrosine kinase receptor that is expressed in the nervous system of Aplysia californica and that is similar to the vertebrate insulin receptor. Binding studies and immunocytochemical staining show that the receptor is abundant in the bag cell neurons. Application of vertebrate insulin to clusters of bag cell neurons stimulates the phosphorylation of the receptor on tyrosine residues, and exposure of isolated bag cell neurons to insulin produces an increase in height and a decrease in duration of the action potentials that
\end{abstract}

can be detected within 15-30 min. These effects were not seen with insulin-like growth factor-1. In voltage-clamped neurons, insulin produces an increase in the amplitude of the voltagedependent $\mathrm{Ca}^{2+}$ current that can be blocked by preincubation with herbimycin A, an inhibitor of tyrosine kinases. Insulin also enhances a delayed $\mathrm{K}^{+}$current. We suggest that insulin-like peptides regulate the excitability of the bag cell neurons.

Key words: insulin receptor; bag cell neurons; tyrosine kinase; Aplysia; calcium channels; potassium channels
Insulin is a peptide growth factor that stimulates growth and differentiation of various kinds of developing cells. For many growth factors, the mechanism of transduction involves binding of the peptide to a membrane-spanning receptor activating a tyrosine kinase in the cytoplasmic domain of the receptor (Rosen, 1987; Cantley et al., 1991). Many receptor and nonreceptor tyrosine kinases are expressed abundantly in the mature nervous system (Lai and Lemke, 1991), and their functions in long-term programs of cell growth and differentiation are well described (Schlessinger and Ullrich, 1992). In neurons, changes induced by protein tyrosine kinases influence clustering of receptors during development (Huganir and Greengard, 1990) and extension of axonal growth cones (Goldberg and Burmeister, 1992; Maness and Cox, 1992). It is unclear, however, whether receptor tyrosine kinases participate in short-term changes of neuronal excitability. Nevertheless, recent evidence suggests that tyrosine kinases regulate ion channels acutely (Huang et al., 1993; Wilson and Kaczmarek, 1993; Wang and Salter, 1994) and that nonreceptor tyrosine protein kinases are needed to induce long-term potentiation (O'Dell et al., 1991) and spatial learning (Grant et al., 1992).

Whether insulin and insulin-like peptides act in synaptic transmission is still uncertain. Havrankova et al. (1978) and Baskin et al. (1987) detected receptors for insulin in mature vertebrate brain. An uptake mechanism from plasma has been described

Received Nov. 11, 1995; revised Dec. 7, 1995; accepted Dec. 8, 1995.

This work was supported by National Institutes of Health Grants NS29809 (J.H.S.), NS18492 (L.K.K.), and AG00486 (E.A.J.), and by Research Scientist Award MH00921 (J.H.S.). D.H.S. was supported by a Medical Research Council of Canada Fellowship. We thank Alice Elste for her excellent technical assistance, John Koester for reading this manuscript, and Ken Kirschner for preparing this manuscript.

Correspondence should be addressed to Dr. James H. Schwartz, Center for Neurobiology and Behavior, Columbia University College of Physicians and Surgeons, 722 West 168th Street, New York, NY 10032.

${ }^{2}$ E.A.J. and D.H.S. contributed equally to the work.

Dr. Solomon's current address: Department of Pharmacology, Columbia University College of Physicians and Surgeons, 630 West 168th Street, New York, NY 10032.

Copyright (C) 1996 Society for Neuroscience $0270-6474 / 96 / 161645-14 \$ 05.00 / 0$
(Schwartz et al., 1992), suggesting that insulin may act through the blood stream as a hormone. In addition, insulin can be synthesized by neurons and is released by depolarization, suggesting that it may act as a neurotransmitter or as a local peptide hormone (Uvnas-Wallenstein, 1981; Boyd et al., 1985). Several electrophysiological actions of insulin have been described, including increased electrical coupling between cultured sympathetic neurons (Wolinsky et al., 1985) and inhibition of spontaneous firing of rat hippocampal neurons (Palovcik et al., 1984). Moreover, identified Aplysia neurons are rapidly hyperpolarized in response to vertebrate insulin (Shapiro et al., 1991).

Insulin-like peptides have also been described in nervous systems of many invertebrates (Thorpe and Duve, 1984; Steiner et al., 1985), notably in the pond snail, Lymnaea stagnalis. These molluscan insulin-like peptides (MIPs) are similar in sequence to mammalian insulin and are believed to regulate reproduction and growth (Smit et al., 1988, 1991). Immunocytochemical evidence indicates that many neurons in the central nervous systems of Lymnaea and Aplysia contain these peptides (Van Minnen and Schallig, 1990).

We report the cDNA cloning and biochemical characterization of an insulin receptor from Aplysia californica and show that it is expressed abundantly in the bag cell neurons, a group of cells that play a key role in the onset of reproductive behaviors (Conn and Kaczmarek, 1989). We also provide functional evidence that bag cell neurons express a receptor similar to the mammalian insulin receptor. Exposure of bag cell neurons to mammalian insulin triggers autophosphorylation on tyrosine residues of the bag cell neuron receptor and enhances voltage-dependent $\mathrm{Ca}^{2+}$ and $\mathrm{K}^{+}$ currents, leading to changes in action potentials.

\section{MATERIALS AND METHODS}

Immunocytochemistry. Anti peptide antibodies against the insulin-binding pocket of the human insulin receptor $\alpha$ subunit (UBI, Lake Placid, NY) were diluted 1:20 for immunocytochemistry and 1:200 for immunoblot analysis. Tissues were fixed in Bouin's fixalive modified for Aplysia [2\% paraformaldehyde, $15 \%$ picric acid, $1 \%$ glacial acetic acid in 0.1 M sodium 
phosphate, $\mathrm{pH} 7.4$, containing $30 \%$ (w/v) sucrose]. Cryostat serial sections $(10 \mu \mathrm{m})$ were mounted on gelatin coated glass slides, rinsed with PBS containing $0.25 \%$ saponin, dehydrated and bleached in $0.3 \% \mathrm{H}_{2} \mathrm{O}_{2}$, and then rehydrated. Sections were blocked with $2 \%$ normal goat serum and incubated in a 1:20 dilution of rabbit anti-insulin receptor antibody (150 $\mu \mathrm{g} / \mathrm{ml})$ overnight at $4^{\circ} \mathrm{C}$. Controls used were normal rabbit IgG $(150$ or 36 $\mu \mathrm{g} / \mathrm{ml}$ ). Slides were rinsed again in PBS/saponin, incubated in rhodamineconjugated goat anti-rabbit IgG, and rinsed and coverslipped with AquaPolyMount (Polysciences, Warrington, PA). Sections were viewed by phase microscopy and epifluorescence with a Leitz microscope (filter pack N-2) and photographed with high-speed Kodak Tri-X film (Rochester, NY).

Intact bag cell clusters and bag cell neurons in culture were examined with a Bio-Rad MRC 1000 confocal apparatus (Bio-Rad, Cupertino, CA). Immunocytochemistry was performed as described above. Images were processed with Bio-Rad's COMOS software package; $1.0 \mu \mathrm{m}$ slices in the $z$-axis were processed and analyzed.

Immunoblot analysis. Tissues were homogenized in $50 \mathrm{~mm}$ Tris- $\mathrm{HCl}$, pH 7.5, $10 \mathrm{mM} \mathrm{MgCl}_{2}, 1 \mathrm{~mm}$ EGI'A, $5 \mathrm{~mm}$ 2-mercaptoethanol, $0.1 \mathrm{~mm}$ phenolmethyl sulfonylfluoride (PMSF; Sigma, St. Louis, MO), $50 \mu \mathrm{g} / \mathrm{ml}$ aprotinin, $5 \mathrm{~mm}$ benzamidine, and $0.1 \mathrm{~mm}$ leupeptin $(400 \mu \mathrm{l})$ with glass-glass homogenizers (Micrometric, Tampa, FL). The homogenate was centrifuged at $1000 \times g$ to remove debris and then at $100,000 \times g$ for $30 \mathrm{~min}$ in a TI - 100 (Reckman, Palo Alto, CA). After SDS-PAGE of 100 $\mu \mathrm{g}$ samples [as measured by the Bradford (1976) method], fractionated proteins were transferred to nitrocellulose $(0.45 \mu \mathrm{m}$, Bio-Rad). Complete transfer was shown by staining with Amido black (Harlow and Lanc, 1988). The membrane was blocked in TBSN ( $25 \mathrm{~mm}$ Tris-HCl, pH 8, 130 mM NaCl, $3 \mathrm{~mm} \mathrm{KCl}$, and $0.1 \%$ Nonidet P-40; Harlow and Lane, 1988) with $3 \%$ bovine serum albumin (BSA) for $1 \mathrm{hr}$ at room temperature and then incubated with primary antibody in TBSN for $1 \mathrm{hr}$ at room temperature. The filter was washed three times for 10 min each with TBSN at room temperature. Detection was with an alkaline phosphataseconjugated secondary antibody kit (Promega, Torrance, CA).

Receptor binding. Aplysia plasma membranes were obtained by the method of Petruzelli et al. (1982), and synaptosomal membranes were obtained by the method of Chin et al. (1989). Competitive binding experiments were performed as described by Czech and Lynn (1973).

cDNA cloning. mRNA was extracted by the micro technique of Chirgwin et al. (1979). In the experiments reported, mRNA was generated from two bag cell neuron clusters removed from a single Aplysia weighing $85 \mathrm{gm}$ (Mariculture Facility, Miami, FL). Coupled cDNA synthesis/PCR (PE/Cetus kit 1402) was performed in a Perkin-Elmer Cetus PCR thermocycler (Emeryville, CA) using the degenerate ramp strategy of Lee and Caskey (1990) for cycles 1-5 and a standard protocol for cycles 6-40. Primers, with sequences from the human insulin receptor kinase domain (Ullrich et al., 1985), were present at a final concentration of $0.4 \mu \mathrm{M}$ each. Primer $1\left(5^{\prime}-\mathrm{TT}_{\mathrm{C}}^{\mathrm{T}} \mathrm{GGNATGGTNTA}{ }_{C}^{\mathrm{T}} \mathrm{GA}_{\mathrm{G}}^{\mathrm{A} G G} \mathrm{3}^{\prime}\right)$ is 120 -fold degenerate, whereas primer $2\left(5^{\prime}-\mathrm{TA}_{\mathrm{G}}^{\mathrm{A}} \mathrm{TA}_{\mathrm{G}}^{\mathrm{A}} \mathrm{TCNGT} \mathrm{C}_{\mathrm{C}}^{\mathrm{T}} \mathrm{TC}_{\mathrm{G}}^{\mathrm{A}} \mathrm{TA}_{1}^{\mathrm{A}} \mathrm{AT}_{\mathrm{G}}^{\mathrm{A}} \mathrm{TC}-3^{\prime}\right)$ is 384 fold degenerate. PCR products were subcloned into pcDNA 1 (Invitrogen, San Diego, CA) using the AT subcloning system (Invitrogen). Scquence analysis was performed on an ABS DNA sequencer at the Columbia University Comprehensive Cancer Center Core Facility.

An Aplysia bag cell neuron cDNA library was constructed with the same input mRNA used for degenerate PCR analysis. The library was made in Lambda Zap II (Stratagene, La Jolla, CA) and was randomprimed. The cDNA was size-fractionated, and cDNAs greater than $1.0 \mathrm{~kb}$ were selected by gel electrophoresis and electroelution; $1 \times 10^{\circ}$ plaques were screened at high stringency with a random-primed PCR-product cDNA fragment corresponding to the Aplysia bag cell neuron insulin receptor kinase domain. Positive plaques were rescreened two additional times, purified by helper phage rescue (Stratagene) into plasmids, and sequenced by the double stranded technique described above. Computer analysis of all clones and inferred translation of the cDNA was performed with DNAStar software (DNAStar, Madison, WI). Southern blot hybridization was performed by the methods of Southern (1975), and Northern blot hybridization was performed by the technique of Sambrook et al. (1989).

Immunocomplex kinase assay and immunoblotting. Bag cell neuron clusters were dissected from $70-100 \mathrm{gm}$ animals in high- $\mathrm{Mg}^{2+}$ dissecting seawater (Eisenstadt et al., 1973). The clusters were pooled in groups of three and placed in $1.5 \mathrm{ml}$ Eppendorf tubes containing seawater (ASW; $460 \mathrm{~mm} \mathrm{NaCl}, 10.4 \mathrm{mM} \mathrm{KCl}, 11 \mathrm{mM} \mathrm{CaCl}, 55 \mathrm{mM} \mathrm{MgCl}_{2}$, and $10 \mathrm{~mm}$ Tris-HCl, pH 7.8). Bovine insulin (Calbiochem, San Diego, CA) was added to a final concentration of $100 \mathrm{~nm}$, and the samples were incubated for $10 \mathrm{~min}$ at $16^{\circ} \mathrm{C}$. The clusters were then homogenized in $400 \mu \mathrm{l}$ of buffer ( $1 \%$ Lubrol, $50 \mathrm{~mm}$ Tris-HCl, $\mathrm{pH} 7.4,10 \mu \mathrm{M}$ Na-orthovanadate, 30 $\mathrm{mm}$ Na-pyrophosphate, $50 \mathrm{~mm} \mathrm{NaF}, 20 \mu \mathrm{M} \mathrm{ZnCl}_{2}, 0.25 \mathrm{~mm} \mathrm{PMSF}$, and 10 $\mu \mathrm{g} / \mathrm{ml}$ each of leupeptin, antipain, pepstatin, and aprotinin) in glass-glass tissue grinders for 3 min on ice.

Samples were then centrifuged at $100,000 \times g$ for $30 \mathrm{~min}$. The supernatants were collected and transferred to $1.5 \mathrm{ml}$ Eppendorf tubes. Tubes were incubated at $4^{\circ} \mathrm{C}$ with rotation for $2 \mathrm{hr}$ after addition of $1 \mu \mathrm{g}$ of anti-insulin receptor $\beta$ subunit monoclonal antibody (AB-3, Oncogene Science, Manhasset, NY). After $20 \mu \mathrm{l}$ protein G-Sepharose beads [50\% (v/v) in lysis buffer; Pharmacia, Piscataway, NJ] were added and the samples were rotated at $4^{\circ} \mathrm{C}$ for $2 \mathrm{hr}$, the immunoprecipitates were collected by centrifugation at $3000 \times g$ for $1 \mathrm{~min}$ and washed twice in 500 $\mu \mathrm{l}$ of homogenization buffer, once in $500 \mu$ of wash buffer $(100 \mathrm{mM} \mathrm{NaCl}$, $50 \mathrm{mM}$ Tris- $\mathrm{HCl}, \mathrm{pH} 7.4$, and $10 \mu \mathrm{M}$ Na-orthovanadate), and once in 500 $\mu \mathrm{l}$ of kinase reaction mix ( $5 \mathrm{~mm} \mathrm{MnCl}, 5 \mathrm{~mm} \mathrm{MgCl}, 10 \mathrm{~mm}$ Tris- $\mathrm{HCl}, \mathrm{pH}$ 7.4, and $10 \mu \mathrm{M}$ Na-orthovanadate). Phosphorylation reactions were performed in $10 \mu \mathrm{l}$ of kinase start mix (kinase reaction mix plus $10 \mu \mathrm{Ci}$ of [ $\left.\gamma^{32} \mathrm{P}\right]$ ATP, $6000 \mathrm{Ci} / \mathrm{mmol}$; DuPont NEN, Boston, MA) for $3 \mathrm{~min}$ at room temperature. The reaction was stopped by adding $100 \mu \mathrm{l}$ of $100 \mathrm{mM} \mathrm{NaCl}$, $50 \mathrm{~mm}$ Tris- $\mathrm{HCl}, \mathrm{pH} 7.4,50 \mathrm{~mm}$ EDTA, and $1 \mathrm{~mm}$ ATP. Immunoprecipitates were sedimented, and SDS sample buffer was added after the supernatant was aspirated. The samples were boiled and then applied to SDS-acrylamide gels. For the immunocomplex assay, $\left[\gamma^{32} \mathrm{P}\right]$ ATP $(6000$ $\mathrm{Ci} / \mathrm{mmol}$ ) was used. For immunoblotting, the SDS gel-electrophoresed proteins were transferred to nitrocellulose (Bio-Rad, Hercules, CA). Nonspecific binding was blocked by incubating the blot in TBSN buffer with $3 \%$ BSA for $1 \mathrm{hr}$ at room temperature. Blots were incubated with anti-phosphotyrosine monoclonal antibody (4G10, UBI) at a dilution of 1:1000 for $1 \mathrm{hr}$ at room temperature in TBSN, followed by an alkaline phosphatase-conjugated goat anti-mouse secondary antibody at 1:3000 in TBSN for $1 \mathrm{hr}$ at room temperature. After three washes of 5 min each in TBSN, immunoreactive proteins were visualized with the alkaline phosphatase-conjugated secondary antibody.

Cell culture. Abdominal ganglia were removed from animals and incubated in $3 \mathrm{ml}$ of filtered ASW containing $1 \mathrm{mg} / \mathrm{ml}$ glucose, $500 \mathrm{U} / \mathrm{ml}$ penicillin and streptomycin, and $13.34 \mathrm{mg} / \mathrm{ml}$ dispase (a neutral protease) for $18 \mathrm{hr}$ at room temperature. Individual clusters were then gently removed from their connective tissue sheaths, and the bag cell neurons were dispersed (using an ASW-containing, sterile Pasteur pipette) onto poly-L-lysine-coated glass coverslips in $35 \mathrm{~mm}$ Corning (Dow Corning, Corning, NY) culture dishes containing ASW. Neurons were stored at $15^{\circ} \mathrm{C}$ and used in experiments within $2 \mathrm{~d}$ (Kaczmarek and Strumwasser, 1984).

Electrophysiology. For current-clamp recordings, glass microelectrodes were made with a Sutter Instruments P-87 puller (Novato, CA). Electrodes filled with $3 \mathrm{M} \mathrm{KCl}$ had resistances of $7-12 \mathrm{M} \Omega$. Neurons bathed in normal ASW were impaled, and current-clamp recordings were obtained with an Axoclamp 2A (Axon Instruments, Foster City, CA) controlled by a Compaq 386/20e host computer. The recordings were allowed to stabilize for several min after impalement. The acquisition and analysis software was pClamp 5.0 (Axon Instruments). Some recordings were made using a WPI S-7100 voltage clamp and saved directly to disk from a digital oscilloscope (Nicolet 4e; Nicolet Instruments, Madison, WI). In these experiments, action potential amplitudes and durations were measured directly from the digital oscilloscope. Trains of action potentials were stimulated by the injection of suprathreshold depolarizing current pulses $(0.125-0.5 \mathrm{nA}$, four to six $130-150 \mathrm{msec}$ pulses, $2 \mathrm{~Hz})$. For all action potential data shown, measurements were taken from the last action potential in each train. Measurements of the duration of the action potentials were made at two-thirds of the peak amplitude (measured from baseline).

For voltage-clamp recordings, ncurons were impalcd with microclectrodes similar to those described for current-clamp recordings. To measure the voltage-dependent $\mathrm{Ca}^{2+}$ current, isolated bag cell neurons were bathed in isosmotic-substituted $\mathrm{ASW}$, in which $\mathrm{NaCl}$ and $\mathrm{KCl}$ were replaced with $460 \mathrm{~mm}$ tetracthylammonium chloride (TEA-Cl) and 10.4 $\mathrm{mM} \mathrm{CsCl}$. $\mathrm{Ba}^{2+}$ currents were recorded by substituting $\mathrm{BaCl}_{2}$ for $\mathrm{CaCl}_{2}$. Inward currents $\left(\mathrm{Ca}^{2+}\right.$ or $\left.\mathrm{Ba}^{2+}\right)$ can be studied in relative isolation using these solutions (Kaczmarek and Strumwasser, 1984). The membrane potential was held at $-60 \mathrm{mV}$ and then depolarized to test potentials between -30 and $+30 \mathrm{mV}$ ( $300 \mathrm{msec}$ pulse, $5 \mathrm{sec}$ interpulse interval) in 5 or $10 \mathrm{mV}$ increments. As described above for current-clamp recordings, voltage-clamp data were acquired with either an Axoclamp $2 \Lambda$ (discontinuous single-electrode voltage-clamp mode) or a WPI 7100 series 
voltage-clamp amplifier. In some experiments, membrane linear leak currents were subtracted from current traces on-line using a conventional $\mathrm{P} / 4$ pulse protocol. Data were digitized, stored, and analyzed as described above. Current measurements were made at peak inward current. $\mathrm{K}^{+}$ currents were recorded from neurons in either normal ASW or ASW containing $10 \mathrm{mM} \mathrm{Co}^{2+}$.

All current- and voltage-clamp recordings were performed in culture dishes containing $3 \mathrm{ml}$ of ASW or substituted ASW as described. Bovine insulin (Collaborative Research, Bedford, MA) was added to dishes by pipette in a $30 \mu$ volume to produce a final bath concentration of $5 \mu \mathrm{M}$. In some experiments, $1 \mathrm{mg} / \mathrm{ml}$ carrier BSA was added to the bath before insulin. In control experiments, BSA had no effect on the electrical propcrtics of the bag ccll ncurons. Insulin-induced changes in clcctrophysiological parameters are typically expressed as a percentage of preexposure control values \pm SEM, and the statistical significance of observed changes was assessed by constructing confidence intervals based on Student's $t$ distribution. Two sample means were compared with Student's $t$ test.

\section{RESULTS}

\section{Distribution of insulin receptor immunoreactivity in Aplysia neurons}

We used anti-peptide antibodies against the extracellular hormone-binding pocket of the mammalian insulin receptor to survey the Aplysia nervous system immunocytochemically. These antibodies have been shown to react with bovine, Xenopus, and Drosophila insulin receptors (Petruzelli et al., 1985). Insulin receptor immunoreactivity was greatest in the bag cell neurons of the abdominal ganglion in which all cells in the cluster appear immunoreactive (Fig. 1). Staining of processes was also seen in the sheath, neuropil, and fibers along some of the caudal nerves of the ganglion. For the most part, this distribution corresponds to that of the egg-laying hormone (ELH) of the bag cell (Chiu and Strumwasscr, 1981). The spccificity of this immunoreactivity was tested by competition with insulin. The insulin receptor antibody, at a concentration of $100 \mu \mathrm{g} / \mathrm{ml}$, was incubated with sections of Aplysia abdominal ganglia for $15 \mathrm{~min}$ and then with $1 \mu \mathrm{M}$ insulin for an additional $10 \mathrm{~min}$ before addition of the labeled secondary antibody. Incubation with insulin extinguished the staining seen with the anti-receptor antibodies (data not shown). Confocal microscopy with $1 \mu \mathrm{m}$ sections revealed that immunoreactivity is present in both cytoplasm and plasma membrane. A similar distribution of immunoreactivity occurred in bag cell neurons in culture for $1 \mathrm{~d}$ in three separate experiments. In contrast to the uniform staining of bag cell neurons in the intact nervous system, only $25 \%$ of the cultured cells appear positive compared with nonimmune $\operatorname{IgG}$ controls (data not shown).

\section{Evidence for an insulin receptor in Aplysia neurons}

Using the same antibody for immunoblotting, we detected a prominent protein component with an approximate molecular weight of 130,000 in extracts of bag cell neurons (Fig. $2 A$ ), but not in the atrial gland or pleural-pedal ganglia. The size of the immunoreactive component is that expected for an insulin receptor (Stadtmauer and Rosen, 1983). Longer exposure of the autoradiogram shown in Figure $2 A$ showed modest immunoreactivity in plasma membranes of buccal muscle (not shown). Quantitation by scanning densitometry of Western blot analysis indicates that the receptor is $47 \pm 6.3(n=3)$ times more concentrated in bag cell neurons than in the muscle membranes.

We also found high-affinity binding sites for insulin in Aplysia neurons. $\left[{ }^{125} \mathrm{I}\right]$ porcine insulin, a ligand that binds with high affinity to insulin receptors in other animals (Cuatrecasas, 1972), binds to Aplysia synaptosomal membranes (Fig. $2 B$ ) and to buccal muscle membranes (data not shown). In all experiments, specific binding, which is saturable, was at least threefold greater than nonspecific binding. Scatchard analysis of specific binding showed a linear slope, indicating a single class of binding sites with a binding constant $\left(K_{\mathrm{d}}\right)$ of $140 \pm 12 \mathrm{~nm}(n=4)$ in synaptosomal membranes (Fig. $2 B$, inset) and $70 \pm 8 \mathrm{~nm}(n=4)$ in buccal muscle membranes. In the same assays, we found the binding constant for human placental plasma membranes to be $7 \mathrm{nM}$.

Next, we examined the specificity of insulin binding to buccal muscle plasma membranes. By immunoblot analysis, we had shown that the receptor is present in buccal muscle. Even though the receptor is not as prevalent as in bag cell neurons, we used this tissue because muscle is much more abundant. The concentration of compctitor requircd to displace half of the porcine insulin bound to buccal muscle membranes was determined for several peptide hormones by displacement binding. The somatomedin, insulin-like growth factor-1 (IGF-1) which, in addition to binding its own unique receptor, binds to mammalian insulin receptors competitively but with a lower affinity than insulin (Schweitzer et al., 1980), displaced insulin with an $\mathrm{IC}_{50}$ of $3.3 \mu \mathrm{M}(n=4)$. IGF-2 displaced insulin with an $\mathrm{IC}_{50}$ of $10.6 \mu \mathrm{M}(n=4)$, whereas the unrelated peptides (vasopressin, oxytocin, and glucagon) all have $\mathrm{IC}_{50} \mathrm{~s}$ of $>100 \mu \mathrm{M}(n=4)$. Similar binding studies were not performed with membranes from bag cell neurons because of the limiting amounts of tissue in these clusters.

\section{Isolation of cDNA clones encoding an Aplysia insulin receptor}

Because there is evidence for insulin receptors in bag cell neurons (Figs. 1,2), we undertook its molecular cloning. The scquence of the cloned Aplysia insulin receptor cDNA is shown in Figure 3. To isolate cDNAs, we took advantage of the identity between the human and the Drosophila insulin receptor kinase domains (Ullrich et al., 1985). Degenerate DNA oligonucleotides were constructed to amplify cDNA encoding an insulin receptor kinase domain from bag cell neuron mRNA. The PCR was performed using the novel degenerate ramp strategy of Lee and Caskey (1990) and resulted in an amplified cDNA containing $510 \mathrm{bp}$, which is $10 \mathrm{bp}$ longer than the cDNA sequence of the human receptor.

A comparison of a portion of the inferred protein sequence with other receptor and nonreceptor tyrosine kinases (Hanks et al., 1988) shows that the insulin kinase cDNA encodes a protein that belongs to the somatomedin family of receptor tyrosine kinases (Fig. 4B). In particular, two sequences, Met-Val-Ala (MVA) and Met-Thr-Arg (MTR), are characteristic of the human placental insulin receptor, the human IGF-1 receptor, and the Drosophila insulin receptor kinase domains (Fig. 4B) but are found neither in the human epidermal growth factor (EGF) receptor kinase domain nor in the kinase domains of the nonreceptor tyrosine kinases human, c-src, and c-abl.

To test whether this amplified cDNA contains a single receptor kinase domain or a heterogeneous population of tyrosine kinase domains, we cut the $510 \mathrm{bp}$ amplified cDNA with the 4 bp endonucleases $H p a \mathrm{I}$ and $A h a \mathrm{II}$. Because the sizes of the resulting fragments resolved by agarose gel electrophoresis add up to the uncut 510 bp cDNA (data not shown), we reasoned that this amplified cDNA is a single sequence and therefore encodes a single insulin receptor kinase domain. We used the $510 \mathrm{bp}$ amplified kinase domain to screen a random-primed, size-selected bag cell neuron cDNA library. We isolated four cDNAs containing $7.1 \mathrm{~kb}$ of overlapping sequence (Fig. 3): $3.7 \mathrm{~kb}$ represents an open reading frame that begins with an initiating Met codon at 


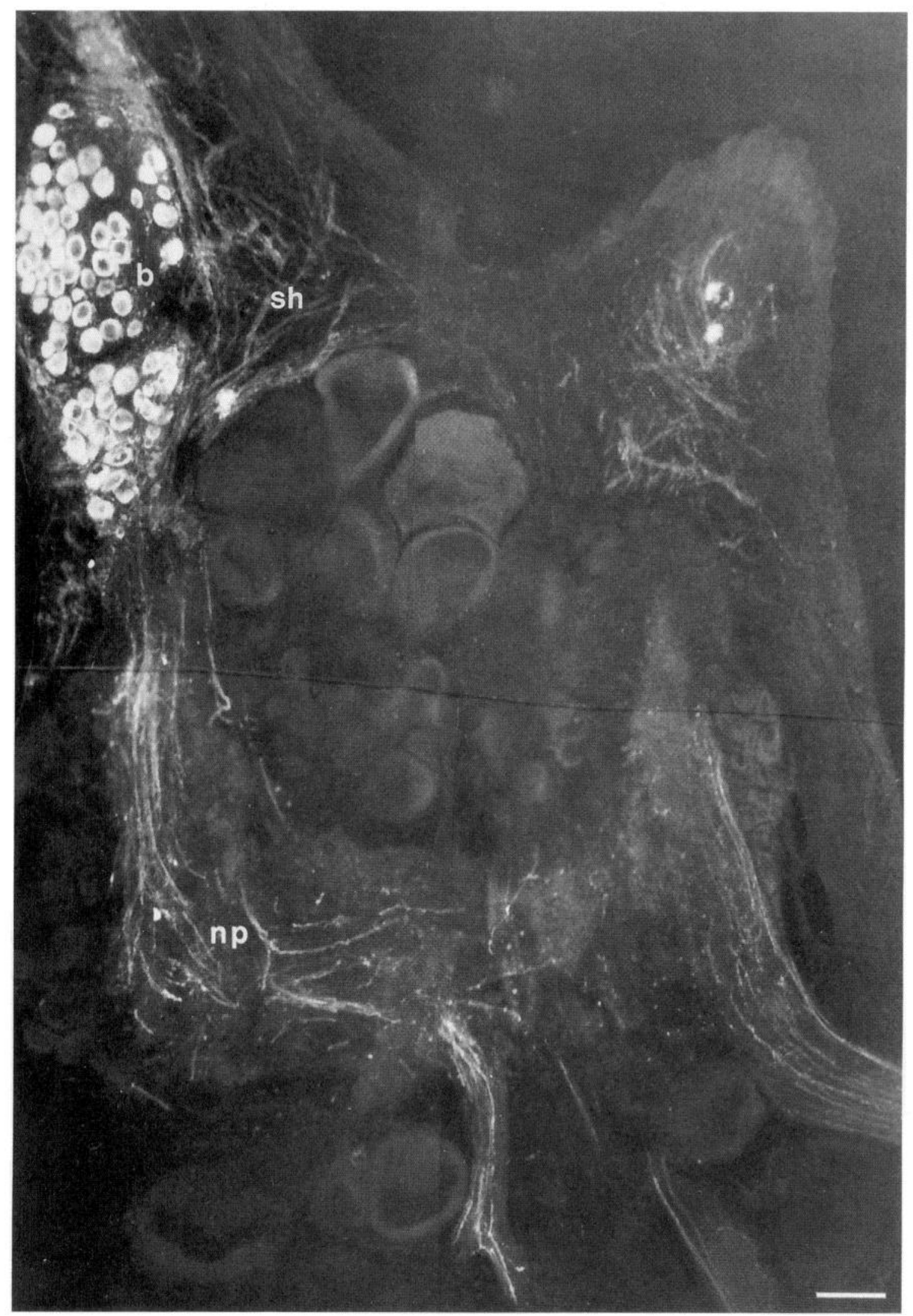

Figure 1. Immunocytochemistry of the abdominal ganglion. The montage of micrographs is from $16 \mu \mathrm{m}$ sections fixed with paraformaldehyde and treated with affinity-purified insulin receptor $\alpha$-subunit antibodies. Prominent immunofluorescence is seen in bag cells $(b)$ and fibers extending into the connective tissue sheath $(s h)$ and neuropil $(n p)$. Only a small portion of the right bag cell cluster is seen because of the asymmetrical angle of the section. Scale bar, $100 \mu \mathrm{m}$. 

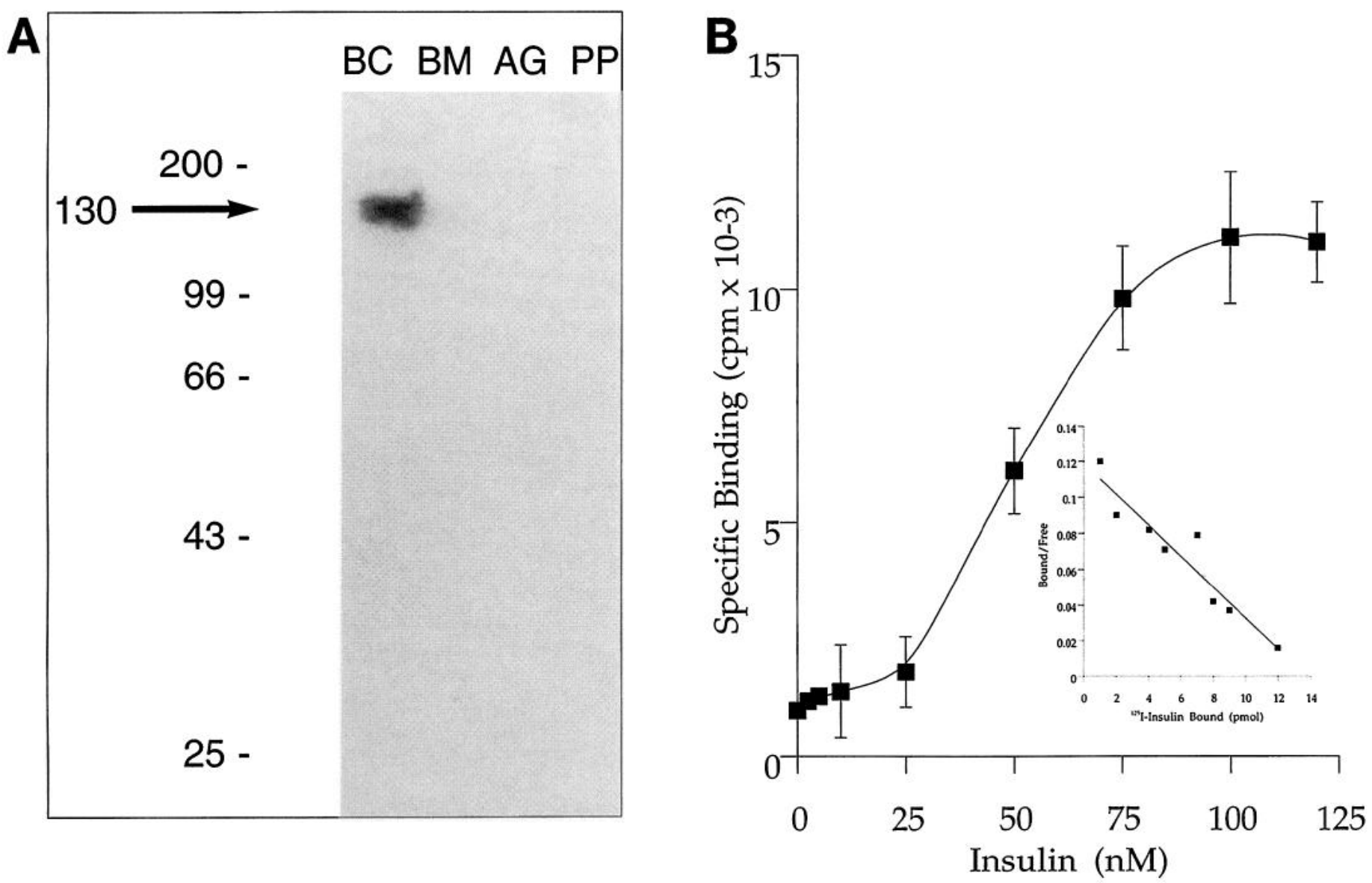

Figure 2. Evidence for an Aplysia insulin receptor. A, Immunoblot analysis of Aplysia protein extracts. Anti-insulin receptor $\alpha$-subunit antibodies at a concentration of $2.5 \mu \mathrm{g} / \mathrm{ml}$ were used to detect an $M_{\mathrm{r}} 130,000$ protein in a bag cell extract (BC lane). No immunoreactivity was seen in extracts of buccal muscle $(B M)$, of abdominal ganglia $(A G)$, or of pleural-pedal ganglia $(P P)$ at this exposure of the autoradiogram. In each lane, $75 \mu \mathrm{g}$ of protein was applied. $B$, Competitive binding of $\left[{ }^{125} \mathrm{I}\right]$ insulin to Aplysia synaptosomal membranes. $\left[{ }^{125} \mathrm{I}\right]$ insulin binds saturably to synaptosomal membranes prepared from the total nervous system. In all instances, specific binding was at least threefold greater than nonspecific binding $(n=4)$. $K_{\mathrm{d}}$ for [ ${ }^{125} \mathrm{I}$ ]porcine insulin was determined to be $140 \pm 12 \mathrm{nM}$ by Scatchard analysis (inset). Error bars are SEM.

position 105 that is within a Kozak (1987) sequence and ends with a stop codon at position 3627 .

A diagram of the structure of the Aplysia insulin receptor is shown in Figure $4 A$. The predicted amino acid sequence of the Aplysia insulin receptor cDNA can be aligned with other members of the somatomedin receptor family. Four of the five tyrosine autophosphorylation sites found in the human kinase domain are conserved. The Aplysia receptor includes a signal peptide from amino acid residues $1-21$ of the $\alpha$ subunit and a membranespanning domain from residues $147-162$ of the $\beta$ subunit of the receptor (Fig. 4A). A sequence of four Arg residues beginning at position 121 presumably is the site of cleavage of the proreceptor into mature $\alpha$ and $\beta$ subunits. The human receptor is cleaved at Arg-Lys-Arg-Arg by a prohormone convertase-like enzyme (Ullrich et al., 1985). Our data suggest, therefore, that the Aplysia receptor, like the human and Drosophila insulin receptors, is transcribed from a single copy gene and has distinct subunits (Rosen, 1987). The $\alpha$ subunit, transcribed from the $5^{\prime}$ end of the gene, is entirely extracellular and binds insulin, whereas the $\beta$ subunit contains an extracellular domain that is connected to the $\alpha$ subunit by disulfide linkages, a membrane-spanning domain, and a tyrosine kinase domain encoded near the $\mathrm{C}$ terminus of the protein.

Southern blot analysis, using cDNA probes from both the conserved kinase domain and a unique sequence from DNA encoding the extracellular $\alpha$ subunit, indicates that the Aplysia insulin receptor ( $A p l-\mathrm{IR}$ ) is encoded by a single gene. By cutting genomic DNA with HindIII, we found that the entire Apl-IR is encoded on a fragment of $\sim 12 \mathrm{~kb}$ (data not shown). Digestion of the DNA with EcoRI, an enzyme that cuts the receptor cDNA once at position 3123 in the putative kinase domain, produced two fragments that were detected when probed at high stringency with the 510 bp PCR probe that also contains this EcoRI site. Northern blot analysis indicated that the gene encodes a transcript of $\sim 9 \mathrm{~kb}$ (data not shown).

\section{Bag cell neurons express a functional insulin receptor tyrosine kinase}

All receptor tyrosine kinases described to date respond to agonist binding by undergoing autophosphorylation on specific tyrosine residues in the tyrosine kinase domain of the receptor (Schlessinger and Ullrich, 1992). To test whether the insulin receptor expressed by the bag cell neurons is autophosphorylated and, more critically, to test whether vertebrate insulin triggers this reaction, we measured the kinase activity of immunoprecipitated receptor and detected phosphotyrosyl groups in the receptor using anti-phosphotyrosine antibodies.

Insulin treatment of bag cell neurons results in increased phos- 
ATGGCCTGGCTGCCGTCCATAAAATTCAGTCGICCCTAATGGTICATITGACCTACGGAT IGAAGTCCTTGAAATTCTTTCAATCCCTAACTGAATTAGCGGCGATCCCGATGGACGCGG 240 Tyr Gly Leu Ala Ala Val His Lys lle Gin Ser Ser Leu Met Vai His Leu Thr Tyr Gly Leu Lys Ser Leu Lys Phe Phe Gin Ser Leu Thr Glu Leu Ala Ala Ile Pro Met Asp Ala

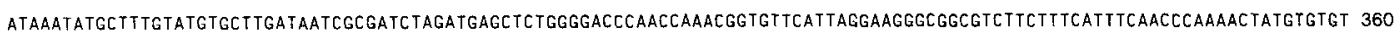
Asp Lys Tyr Ala Leu Tyr Val Leu Asp Asn Arg Asp Leu Asp Glu Leu Trp Gly Pro Asn Gin Thr Val Phe lle Arg Lys Giy Giy vai Phe Phe Hils Phe Asn Pro Lys Leu Cys Val CCACCATTAACCAGTIGCI GCCCAIGCIGGCCICLAAGCCAAAGTTTTTTGAAAAGTCAGATGTGGGCGCAGACTCGAATGGAAACCGCGGATCATGTGGAACAGCCGT TCTCAATGTCA 480 Ser Thr lile Asn Gin Lou Leu Pro Met Leu Ala Ser Lys Pro Lys Phe Phe Glu Lys Ser Asp Val Gly Ala Asp Ser Asn Gly Asn Arg Gly Ser Cys Gly Thr Alo Vai Leu Asn Val

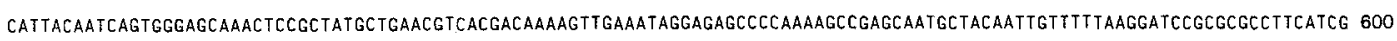
Thr Leu Gin Ser Val Gly Ala Asn Ser Ala Met Leu Asn Val Thr Thr Lys Val Glu Ile Gly Glu Pro Gin Lys Pro Ser Asn Ala Thr lle Val Phe Lys Asp Pro Arg Ala Phe Ile

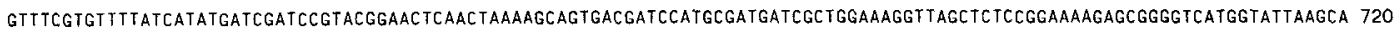
Gly Phe val Phe Tyr His Mat lle Aso Pro Tyr Gly Thr Gln Lou Lys Nla Val Thr llo His ala Met llo Ala Gly Lys Val Ser Ser Pro Glu Lys Ser Gly Val Met Vai Leu Ser

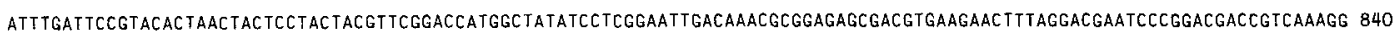
Asn Leu Jle Pro Tyr Thr Asn Jyr Ser Tyr Tyr Val Arg Thr Met Alo Ile Ser Ser Glu Leu Thr Asn Ala Glu Ser Asp Val Lys Asn Phe Arg Thr Asn Pro Gly Arg Pro Ser Lys

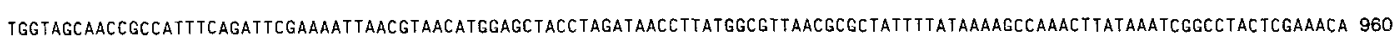
Val Val Ala Thr Ala Ile Ser Asp Ser Lys Ile Asn Val Thr Trp Ser Tyr Leu Asp Asn Leu Met Alo Leu Thr Arg Jyr Phe Ile tys Ala Lys Leu lle Asn Arg Pro Thr Arg Asn

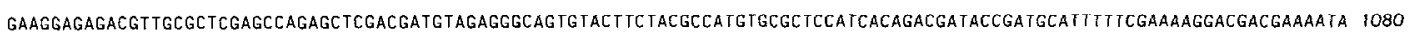
Arg Arg Arg Asp Val Ala Leu Glu Pro Glu Leu Asp Asp Yal Glu Gly Ser Val Leu Leu Arg His Val Arg Ser lle Thr Asp Asp Thr Asp Ala Phe Phe Glu Lys Asp Asp Glu Asn CCTATAAAGACGAAGAAGACTTGTCCTCCAACAAACAATTCTATGAGGTGTTJGCCAAGGAATTGCCACCAAATCAAACACATTTTGTCTTIGAAAAAAATAACCGgGATTACIGTACTG 1200 Thr Tyr Lys Aso Glu Glu Asp Leu Ser Ser Asn Lys Gin Phe Tyr Glu Val Phe Alo Lys Glu Leu Pro Pro Asn Gln Thr His Phe Val Phe Glu Lys Asn Asn Arg Asp Tyr Cys Thr

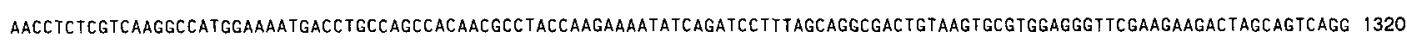
Glu Fro Leu Val Lys Ala Met glu Asn Asp Leu Pro Ala Thr Thr Pro Thr Lys Lys lle Ser Asp Pro leu Ala Cly Asp Cys Lys Cys Yal Glu Gly Ser byo Lys Thr Ser Ser Cln

AATACGATGATCGTAAAGTTCAAGCGGGCATGGAGTT TGAGAACGCGTTGCAAAACTTTATATTTGTTCCAAACATTCGgAAAAGCAAGAATgGATCGTCTGACAAATCAGACGGAGCGG 1440 Glu Tyr Asp Asp Arg Lys Val Gin Ala Gly Met Glu Phe Glu Asn Ala Leu Gin Asn Phe lle Phe Val Pro Asn lle Arg lys Ser Lys Asn Gly Ser Ser Asp Lys Ser Asp Gly Ala AAGGTGCAGCTCTCGATTCTAATGCTATTCCAAATGGAGGAGCTACTAACCCTICACGTAGAAGgAGAGACGTTGCGCTCGAGCCAGAGCTCGACGATGTAGAGgGCAGTGTACTTCTAC 1560 Glu Gly Ala Ala Leu Asp Ser Asn Ala lle Pro Asn Gly Gly Alo Thr Asn Pro Ser Arg Arg Arg Arg Asp Val Ala Leu Glu Pro Glu Leu Asp Asp Val Glu Gly Ser Val Leu Leu

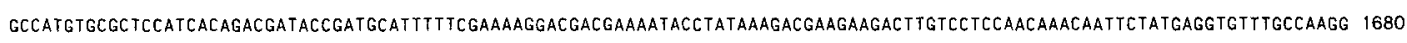
Arg His Val Arg Ser lle Thr Asp Asp Thr Aso Ala Phe Pho Glu lys Asp Asp Glu Asn Thr Jyr Lys Asp Glu Glu Asp Leu Ser Ser Asn Lys Gln Phe Tyr Glu Val Phe Alo Lys

AATTGCCACCAAATCAAACACATTTTGTCTTTGAAAAAC TGCGCCACTTCACCTACGCTATCTTCGTGGTAGCCTGTAGAGAAGAAATCCCCAGCGAAAAATTAAGGGACACCAGTTTTA 1800 Glu Leu Pro Pro Asn Gin Thr His Phe Val Phe Giu Lys Leu Arg His Phe Thr Tyr Alo lle Phe Val Val Alo Cys Arg Glu Glu Jle Pro Ser Glu Lys Leu Arg Asp Thr Ser Phe

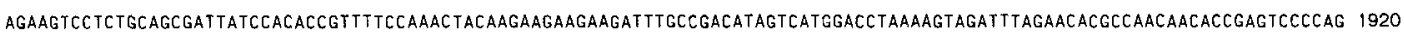

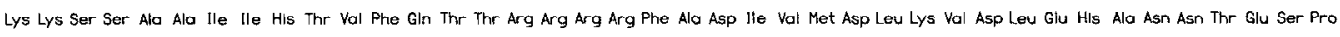

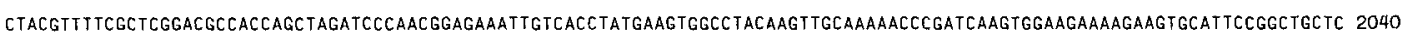
Ala Thr Phe Ser Leu Gly Arg His Gin Leu Asp Pro Asn Gly Glu Ile Val Thr Tyr Glu Val Ala Tyr Lys Leu Gin Lys Pro Asp Gin Val Gtu Glu Lys Lys Cys Ile Pro Ala Ala

GACTTCAACCAGACTGCCGITATTTAATAAAGCTCAACGAGgGCCTTTACAGCTTCAGgTGCGAGCCAATTCAATAGCGgGATACGGCGATTTCACGGAAGTCGAACATATAAAAGTTG 2160 Arg Leu Gin Pro Asp Cys Arg Leu Phe Asn Lys Alo Gin Arg Gly Pro Leu Gln Leu Gin Val Arg Alo Asn Ser lle Ala Gly Tyr Gly Asp Phe Thr Glu Val Glu His lle Lys Val

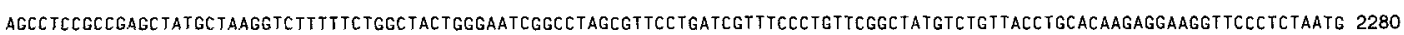
Glu Pro Pro Pro Ser Tyr Ala lys Val Phe Phe Trp Leu Leu Gly lle Gly Leu Ala Phe Leu lie Val Ser Leu Phe Gly Tyr Val Cys Tyr Leu His Lys Arg Lys Vol Pro Ser Asn

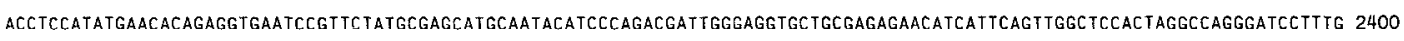
Asp Leu His Met Asn Thr Glu Val Asn Pro Phe Tyr Ala Ser Met Gln Tyr Ile Pro Asp Asp Tro Glu Voi Leu Arg Glu Asn Ile lle Gln Leu Ala Pro Leu Gly Gin Giy Ser Phe

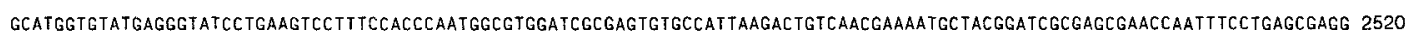
Gly Met Voi Tyr Glu Gly lle Leu Lys Ser Phe Pro pro Asn Giy val Asp Arg Gilu Cys Alo lle lys Thr val Asn Glu Asn Ala Thr Asp Arg Glu Arg Thr Asn Phe Leu Ser Glu

CGAGCGTCATGAAGGAGTTCGATACGTATCATGTCGTAAGATTGCTCGGTGTTTGTTCCAGGGGTCAGCCGGCTCTGGTGGTCATGGAGCTAATGAAGAAGGTTGAGCTTAAGTCCTATT 2640 Alo Ser Yol Met Lys Glu Phe Asp Thr Tyr His Val Val Arg Leu Leu Gly Val Cys Ser Arg Gly Gln Pro Ala Leu Val Val Met Glu Leu Met Lys Lys Val Glu Leu Lys Ser Tyr

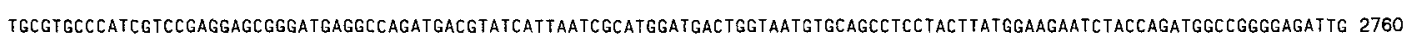
Leu Arg Ala His Arg Pro Arg Ser Gly Met Arg Pro Asp Asp Val Ser Leu lle Ala Trp Met Thr Gly Asn Val Gln Pro Pro Thr Tyr Gly Arg lle Tyr Gln Met Alo Gly Glu lle CGGATGGCATGGCATATITGGCCGCCACGAAGTTCGTCCATCGTGATCTTGCAGCTCGAAATTGCATGGTTGC TGATGATTIGACGGTGAAATTGGTGACTTTGGAATGACCCGTGACA 2880 Ala Asp Gly Met Ala Tyr Lou Ala Ala Thr Lys Phe Val his Arg Asp Leu Alo Ala Arg Asn Cys Met Val Alo Asp Asp Leu Thr Val lys lle Gly Asp Phe Gly Met Thr Arg Asp TCTATGAGAGGGATTACTATCGGAGGGCACAAAAGGCCTGCTGCCAGTTCGCTGGATGCCACCGgAGAGCTTGCGAGATGGTGTCTACTCTAGTGCCAGTGATGTATTCAGCTTTGGAG 3OOO lle Tyr Glu Thr Asp Tyr Tyr Arg lys Gly Thr Lys Gly Leu Leu Pro Val Arg Trp Met Pro Pro Glu Ser Leu Arg Asp Gly Val Tyr Ser Ser Alo Ser Asp Val Phe Ser Phe Gly TGGTICTCTGGGAAATGGCCACCTTAGCGGC TCAGCCATACCAGGGACTTTCCAACGAGCAAGTCCTGCGTTACGTCATCGATGGCGGTGTTATGGAGAGGCCGGAAAATTGICCTGATT 3120 Val Val Leu Trp Glu Met Ala Thr Leu Ala Ala Gln Pro lyr Gin Gly Leu Ser Asn Glu Gin Val Leu Arg Tyr Val Ile Asp Gly Gly Val Met Giu Arg Pro Glu Asn Cys Pro Asp TTCTGCATAAACTAATGCAAAGGTGCTGGCATCATAGGTCTTCGGCGAGACCCAGTTTICTGGATATCATTGCGTATCTCGAACCACAATGCCCCAATTCACAATTTAAGGAAGTATCCT 3240 Phe Leu His lys Leu Met Gin Arg Cys Trp His His Arg Ser Ser Ala Arg Pro Ser Phe Leu Asp lie lle Alo Tyr leu Glu Pro Gin Cys Pro Asn Ser Gin Phe Lys Giu Val Ser

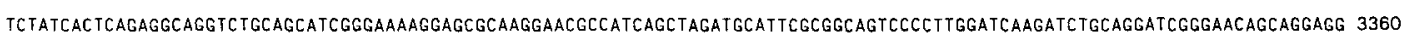
Phe Tyr HIs Ser Glu Alo Gly Leu Gln His Arg Glu Lys Glu Arg Lys Glu Arg His Gin Leu Asp Ala Pho Ala Ala val Pro Leu Asp Gln Asp Leu Gin Asp Arg Glu Gln Gin Glu ATGCTAGCACACCTTIACGAATGGGCGATTATCAGCAGAACTCCTCGTTGGATCAACCGCCCGAAAGCCCCATCGCCATGGTTGATGATCAGGGTTCTCACTTGCCATTTAGCCTGCCAT 3480 Asp Ala Ser thr Pro leu Arg Met Gly asp Tyr Gin Gin Asn Ser Ser Leu Asp Gin Pro Pro Giu Ser Pro Ilo Ala Met Val asp asp Gin Gly Ser His Leu Pro Phe Ser Leu Pro

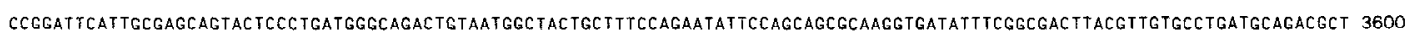
Ser Gly Phe lle Ala Ser Ser Thr Pro

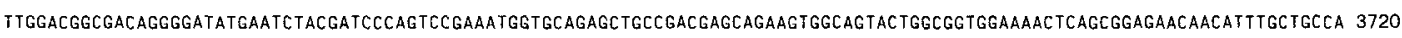
AGAAAGGGTCGCAAGCCTA 3739

Figure 3. cDNA and protein sequence of the Aplysia bag cell neuron insulin receptor. The nucleotide sequence of the strand corresponding to the mRNA is shown. Numbers above the cDNA sequence refer to the position of the nucleotide in reference to the start site of translation. The complete open reading frame begins with the initiation Met codon at position 105 and ends with the stop codon at position 3627. The Genbank accession number for $A p l$-IR is U31747. 


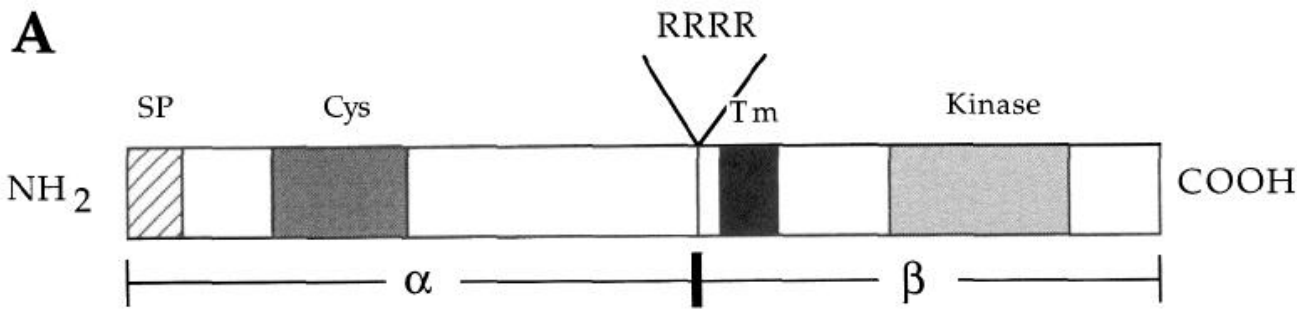

B

\begin{abstract}
MAGE I ADGMAYLAATKF VHRDLAARNCMVAQDKTVK I GDFGMTR
|| || || || || || || || || || || ||. ||. || || || || || || || || || || || || || || ||: || || || || || || || || || || || || || MAGE I ADGMA YLNANKF VHRDLAARNCMVAEDFTVK I GDFGMTR $\uparrow 1120$

$\uparrow 1150$
\end{abstract}

MAAE I ADGMAVLNAKKF VNRDLAARNCMVAHDF TVK I GDFGMTR VAIE I ADGMA YLAAKKFVNRDLAARNCMVADDL TVK I GDFGMTR

WCVQ I AKGMNYLEDRRL VNRDLAARNVLVKTPQHVK I TDFGLAK MAAQ I ASGMA YVERMNYVNRDLRAAN I LVGENL VCKVADGFLAR MATQI SSAMEYLEKKNF INRDLAARNCL VGENHL VKVADFGLSR

\section{Aplysia Bag Cell IR}

Human Placental IR

Human IGF-1

Drosophila IR

Human EGF-R

Human c-src

Human c-abl
Figure 4. Functional domains of the Aplysia bag cell neuron insulin receptor and relationship of the Aplysia bag cell neuron insulin receptor kinase domain to the somatomedin receptor family kinases. $A$, The complete cDNA encodes both the $\alpha$ and $\beta$ subunits. At the $\mathrm{N}$ terminus, a possible signal peptide (SP) directs the protein through the plasma membrane. The Cys-rich domain (Cys) is believed to bind insulin (Ullrich et al., 1985). The tetra-Arg site (RRRR) is a possible cleavage site between the extracellular $\alpha$ subunit and the transmembrane $\beta$ subunit. A 15-amino-acid hydrophobic domain follows this putative cleavage site and is likely to be the transmembrane-spanning domain $(\mathrm{Tm})$. A 187-amino-acid kinase domain (shad$e d$ ) near the $\mathrm{C}$ terminus is $88 \%$ identical to the Drosophila kinase domain and $73 \%$ identical to the human kinase domain. $B$, Sequence analysis of the degenerate PCR-amplified Aplysia bag cell neuron kinase domain reveals that it shares amino acid residues $M V A$ and MTR found only in the cloned somatomedin receptor family of kinases but not in the kinase domains of other receptor and nonreceptor tyrosine kinases. phorylation of the $\beta$ subunit of the bag cell neuron insulin receptor. As shown in Figure $5 A$, when immunoprecipitates of the 95 $\mathrm{kDa} \beta$ subunit of the receptor from bag cell neurons were incubated with $\left[\gamma^{32} \mathrm{P}\right] \mathrm{ATP}$, autophosphorylation also could be detected (lane 2). Incubation of the clusters of bag cell neurons with bovine insulin $(100 \mathrm{nM})$ for $10 \mathrm{~min}$ before homogenization, however, resulted in a 4.2 -fold increase in incorporation of labeled phosphate into the protein $(n=4$; lane 1$)$. Pretreatment of the cells with $390 \mathrm{~nm}$ herbimycin A, a selective tyrosine kinase inhibitor (Uehara et al., 1986), for $1 \mathrm{hr}$ before adding insulin to the cells blocked the increase in phosphate incorporation $(n=4$; lanes 3 and 4). Addition of herbimycin A to immunoprecipitates (after immunoprecipitation of the receptor but before the addition of $\left.\left[\gamma^{32} \mathrm{P}\right] \mathrm{ATP}\right)$ decreased, but did not block, the insulin response (lanes 5 and 6 ).

The data shown in Figure $5 B$ confirm that the insulindependent autophosphorylation of the receptor is on tyrosine residues. In this experiment, the immunoprecipitates from an immunocomplex assay performed in the presence of unlabeled ATP were transferred to a nitrocellulose filter and probed with an anti-phosphotyrosine antibody. Insulin caused the phosphotyrosine content of the receptor to increase. As with the kinase assay, preincubation of cells with herbimycin A inhibited the increase in phosphotyrosine content; it also inhibited insulinstimulated phosphorylation on tyrosine residues to a lesser degree when added after immunoprecipitation but before the kinase reaction.

\section{Insulin changes the shape of action potentials}

To determine whether exposure to insulin affects the electrical properties of bag cell neurons, we tested the acute actions of the peptide on individual, isolated neurons $(n=8)$ maintained in cell culture (Kaczmarek and Strumwasser, 1981) and also compared populations of acutely treated and untreated cultured cells $(n=$ 27). In individual cells, concentrations of insulin of $100 \mathrm{nM}, 1 \mu \mathrm{M}$, and $5 \mu \mathrm{M}$ caused an increase in the height of action potentials, but $10 \mathrm{~nm}$ insulin was without effect (data not shown). In all of the data presented, the $5 \mu \mathrm{M}$ concentration was used. The typical shape of action potentials evoked by a single depolarizing current pulse is shown in Figure $6 A$ for an isolated bag cell neuron in the presence and absence of insulin. At the onset of the current injection, the neuron begins to depolarize toward action potential threshold. The rapid rising phase of the action potential occurs after a characteristic latency and the membrane potential then repolarizes before the end of the $150 \mathrm{msec}$ stimulus. After insulin was added, the latency was reduced from the onset of the pulse to the upstroke of the action potential. The amplitude of action potentials was also increased. These changes occurred with no change in the resting potential of the cells (control resting potential, $-47 \pm 3 \mathrm{mV}$; after insulin, $-45 \pm 4 \mathrm{mV} ; n=8)$.

Typically, the effect of insulin was evident within $15-30 \mathrm{~min}$ of application. The time course of the increase in action potential amplitude induced by insulin is shown in Figure $7 A$, and the combined data for eight cells are shown in Figure $7 B$. The heights of action potentials evoked by current pulses in different bag cell neurons can vary from 35 to $70 \mathrm{mV}$. The heights of action potentials have therefore been normalized to the mean control value measured in the same cells during the $15 \mathrm{~min}$ period before insulin treatment (labeled 100 at time 0 in the graph). After $1 \mathrm{hr}$ of exposure to insulin, the mean action potential amplitude increased significantly in all eight cells (from $49.7 \pm 4.8$ to $57.04 \pm$ $4.61 \mathrm{mV}, p<0.02 ; n=8)$. Neurons treated with vehicle $(n=13)$ showed no increase in height of action potential. On the contrary, the spike amplitude gradually declined during the same time period (from $62.01 \pm 5.75$ to $51.70 \pm 5.67 \mathrm{mV}, p<0.001$ ). Moreover, the insulin-related peptide IGF-1 $(1 \mu \mathrm{g} / \mathrm{ml} ; n=4)$ also produced no significant change in the shape of action potentials (Fig. $6 D$; control height, $65.6 \pm 7.01 \mathrm{mV}$; after IGF-1, $64.7 \pm 7.4$; $p<0.56)$. 


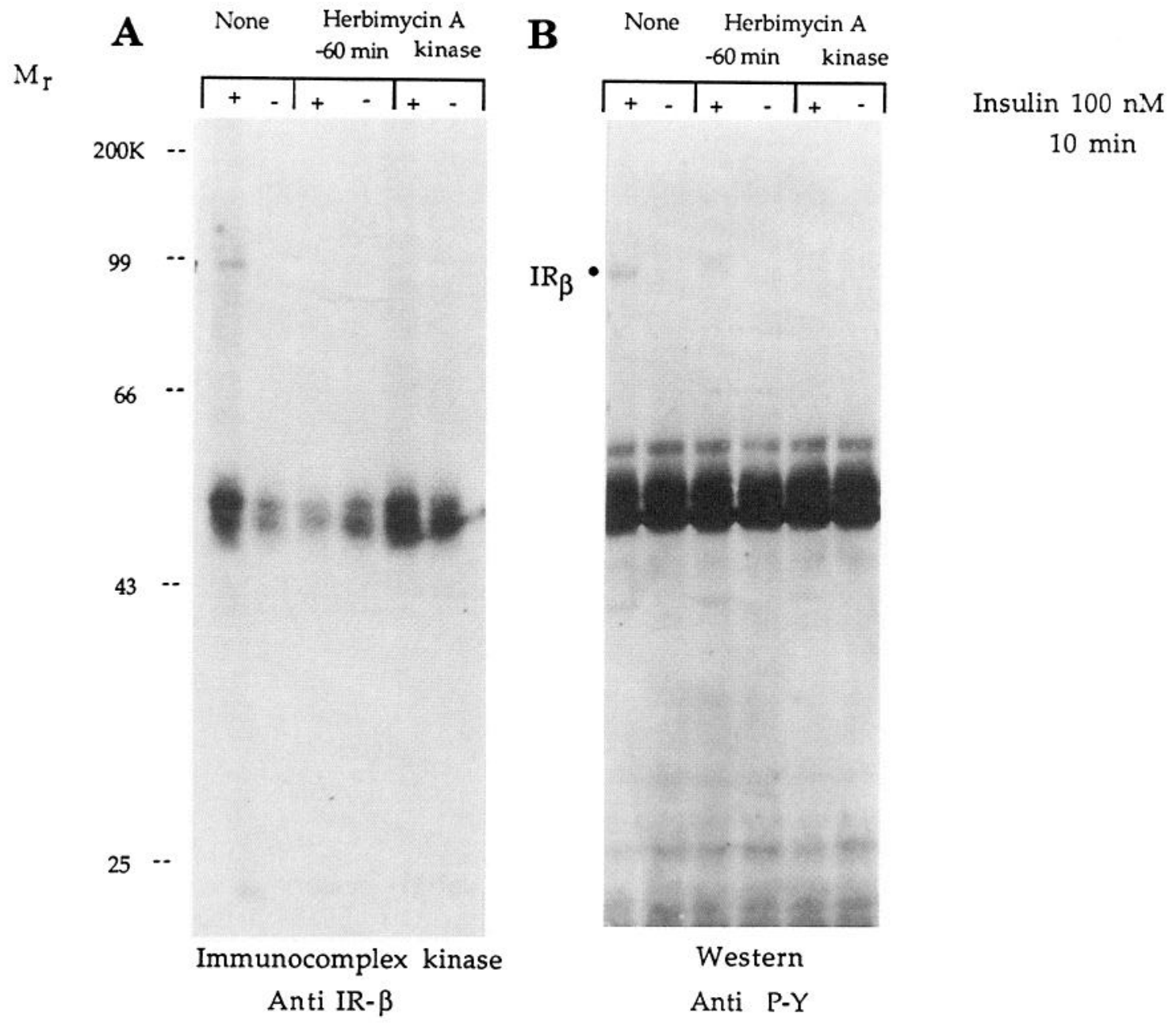

Figure 5. Insulin-sensitive tyrosine kinase activity in bag cell neurons. For these experiments, bag cell clusters (3/lane) were exposed to insulin in resting ASW (+) or resting ASW alone (-). In each set of experiments, some clusters were treated with herbimycin A for 60 min before cell lysis ( 60 min) or with herbimycin A during the kinase reaction (kinase). In parallel, control clusters were not exposed to the tyrosine kinase inhibitor (None). A, Immunocomplex kinase assay of bag cell neurons. The insulin receptor tyrosine kinase was immunoprecipitated using a monoclonal antibody raised against the vertebrate insulin receptor $\beta$ subunit. The immunoprecipitate was then subjected to an in vitro receptor autokinase assay. This assay was performed by adding $\left[\gamma^{32}\right.$ P]ATP to the immunoprecipitated receptor (now coupled to protein A-Sepharose beads) suspended in kinase buffer (see Materials and Methods). After the kinase reaction, the autophosphorylated receptor was released from the beads by boiling in SDS-PAGE sample buffer and electrophoresed. The gel was fixed, autoradiographed, and photographed. The bag cell insulin receptor-autophosphorylated $\beta$ subunit migrates at $\sim 95 \mathrm{kDa}$. The migration distances of protein standards are indicated at the left side of the gel. $B$, A Western blot of a parallel immunocomplex assay. In this experiment, the immunoprecipitates were separated by SDS-PAGE after the kinase reaction with unlabeled ATP, transferred to a nitrocellulose filter, and then reacted with an anti-phosphotyrosine monoclonal antibody followed by alkaline phosphatase-conjugated anti-mouse IgG. The results are representative of four experiments. The $\sim 50 \mathrm{kDa}$ bands seen in both $A$ and $B$ are $\mathrm{IgG}$ heavy chains from the primary antibody brought down in the immunoprecipitation and phosphorylated in the kinase reaction.

In several cells, insulin produced additional changes in the voltage response of bag cell neurons to current pulses. In four neurons, the excitability of the cells was increased to the point that the 150 msec constant current pulses, which had been adjusted to trigger only a single spike before the application of insulin, evoked extra action potentials after insulin (see Fig. $6 A$ ). In two cells, insulin treatment induced a hump that arose out of the falling phase of the action potentials (Fig. $6 B, C$ ). Insulin treatment also typically decreased the duration of action potentials (see Fig. 6 $A$ ). Measurements of width were made at a voltage corresponding to $66 \%$ of the height of the action potential. The mean time course for the decrease in action potential duration for seven neurons is shown in Figure $7 C$. (Measurements could not be made in one cell because of the emergence of a hump that occurred at a potential positive to $66 \%$ of spike height.) At $1 \mathrm{hr}$ of insulin treatment, the duration was reduced significantly to $78 \pm 7.7 \%$ of the mean control value $(p<0.02)$.

We performed additional experiments in which we sampled the amplitudes of action potentials in a population of bag cell neurons treated acutely with insulin and in a control population of cells dissociated from the same bag cell clusters. The mean action potential height of the insulin-treated neurons was $80.6 \pm 1.8 \mathrm{mV}$ ( $n=27$ ), which is significantly different from the corresponding value of $69.5 \pm 3.1 \mathrm{mV}(n=22)$ in the control neurons from the same cluster $(p<0.003)$.

\section{Insulin increases voltage-dependent $\mathrm{Ca}^{2+}$ current}

The voltage-dependent $\mathrm{Ca}^{2+}$ current underlies the rising and plateau phases of action potentials of bag cell neurons in primary culture (Kaczmarek and Strumwasser, 1984). We therefore exam- 

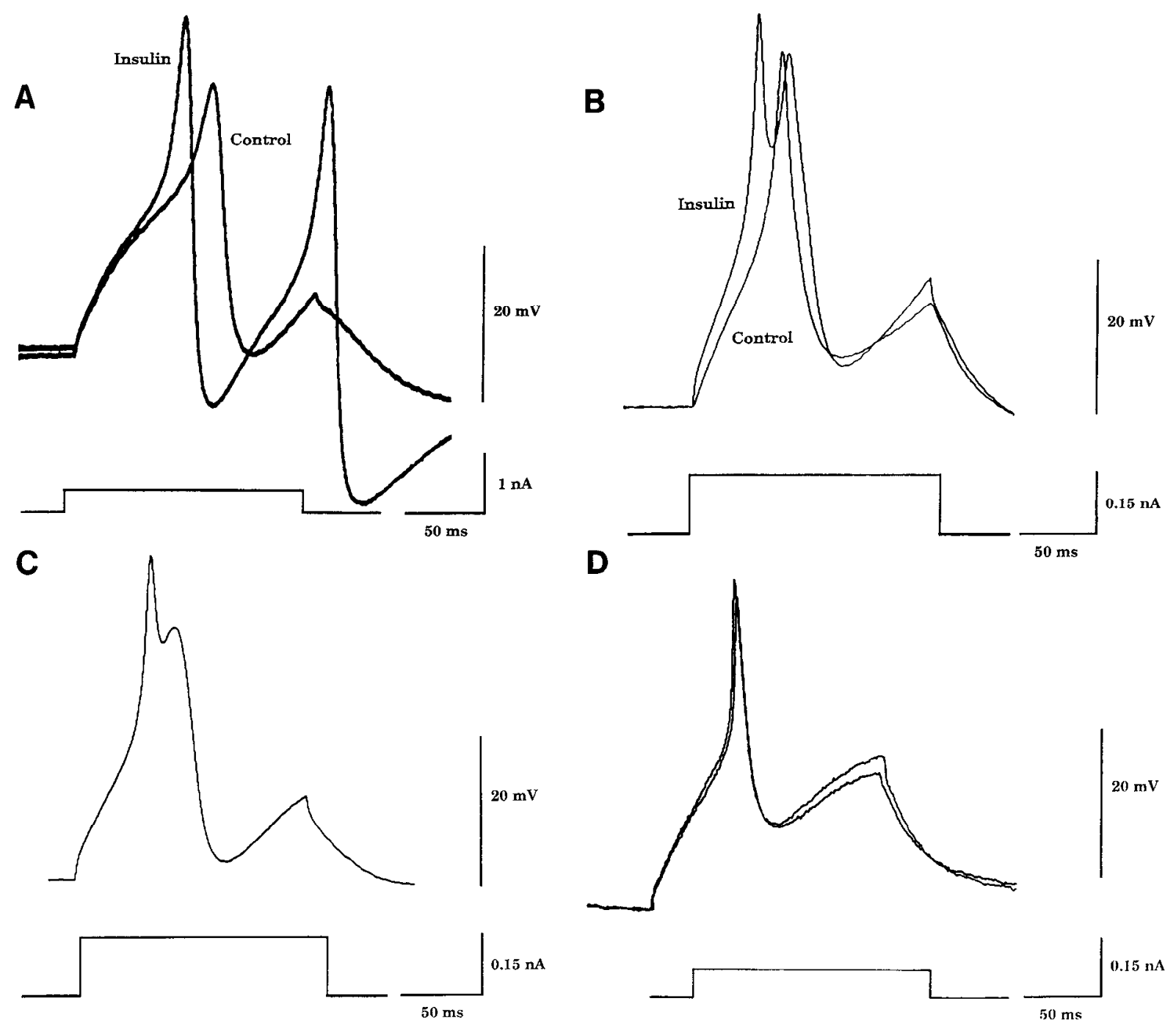

Figure 6. Insulin alters the shape of the bag cell neuron action potential. $A$, The action potentials shown were evoked by a depolarizing current pulse $(0.25 \mathrm{nA}, 150 \mathrm{msec}$ ) before and $30 \mathrm{~min}$ after bath application of $5 \mu \mathrm{M}$ insulin. $B$, Action potentials (evoked by $0.25 \mathrm{nA}$ depolarizing current pulse) recorded from another cell before and $50 \mathrm{~min}$ after the addition of $5 \mu \mathrm{M}$ insulin. $C$, Insulin sometimes caused the appearance of a hump on the falling phase of the action potential. This recording is from the same cell as the recording in $B . D$, Superimposed action potentials evoked by a depolarizing current pulse before and $35 \mathrm{~min}$ after bath application of IGF-1 $(1 \mu \mathrm{g} / \mathrm{ml})$.

ined the effect of insulin on inward currents in these cells. Inward divalent currents were isolated by replacing $\mathrm{NaCl}$ with $460 \mathrm{~mm}$ TEA-Cl and $\mathrm{KCl}$ with $10.4 \mathrm{~mm} \mathrm{CsCl}$ in ASW. In most experiments, we used $\mathrm{Ba}^{2+}$ ions as the charge carrier, replacing $\mathrm{CaCl}_{2}$ with $10.4 \mathrm{mM} \mathrm{BaCl}_{2}$.

Application of insulin produced an increase in both the peak and the sustained components of the $\mathrm{Ba}^{2+}$ current (Fig. 84). $\mathrm{Ba}^{2+}$ currents were measured in isolated bag cell neurons during step depolarizations from a holding potential of -60 to $-10 \mathrm{mV}$. Currents are shown before and $30 \mathrm{~min}$ after the application of 5 $\mu \mathrm{M}$ insulin. Treatment with insulin produced a significant increase in peak $\mathrm{Ba}^{2+}$ current $(18 \pm 7 \%)$ above the mean control current amplitude in 14 cells $(p<0.04)$. The increase in current occurred $>20-40 \mathrm{~min}$ after treatment with insulin. The time course of the effect on $\mathrm{Ba}^{2+}$ current obtained in four insulin-treated cells and three control cells in which $\mathrm{Ba}^{2+}$ currents were measured at $5 \mathrm{~min}$ intervals during $50 \mathrm{~min}$ of stable recording is illustrated in Figure $8 B . \mathrm{Ba}^{2+}$ currents run down slowly in untreated cells but increase in insulin-treated neurons during the same time period. Record- ings were also made in five more cells in which $\mathrm{Ca}^{2+}$ ions were used as the charge carrier. Both the percent increase in the amplitude of the currents after treatment and the time course of the effect of insulin were similar to those seen in the experiments with $\mathrm{Ba}^{2+}$. Insulin increased the mean inward $\mathrm{Ca}^{2+}$ current by 15 $\pm 4 \%(p<0.01 ; n=5)$.

Because the amplitude of $\mathrm{Ba}^{2+}$ currents decreases in control cells during $1 \mathrm{hr}$ or more of recording, we also compared the amplitude of currents in populations of neurons from the same bag cell clusters. We found that neurons treated with insulin for 90 min had significantly larger $\mathrm{Ba}^{2+}$ currents than control untreated cells from the same cluster (Fig. $8 C, D ; p<0.001, n=4$ ). Because activation of the insulin receptor protein kinase is inhibited by herbimycin $\mathrm{A}$, we also tested the effects of this tyrosine kinase inhibitor on the enhancement of $\mathrm{Ba}^{2+}$ currents by insulin. Herbimycin $\mathrm{A}(1.7 \mu \mathrm{M})$ alone had no effect on the amplitude of $\mathrm{Ba}^{2+}$ currents $(p<0.3, n=4)$, but abolished the increase in response to insulin (Fig. $8 C, D$ ).

$\mathrm{Ca}^{2+}$ currents in bag cell neurons are known to be enhanced by 

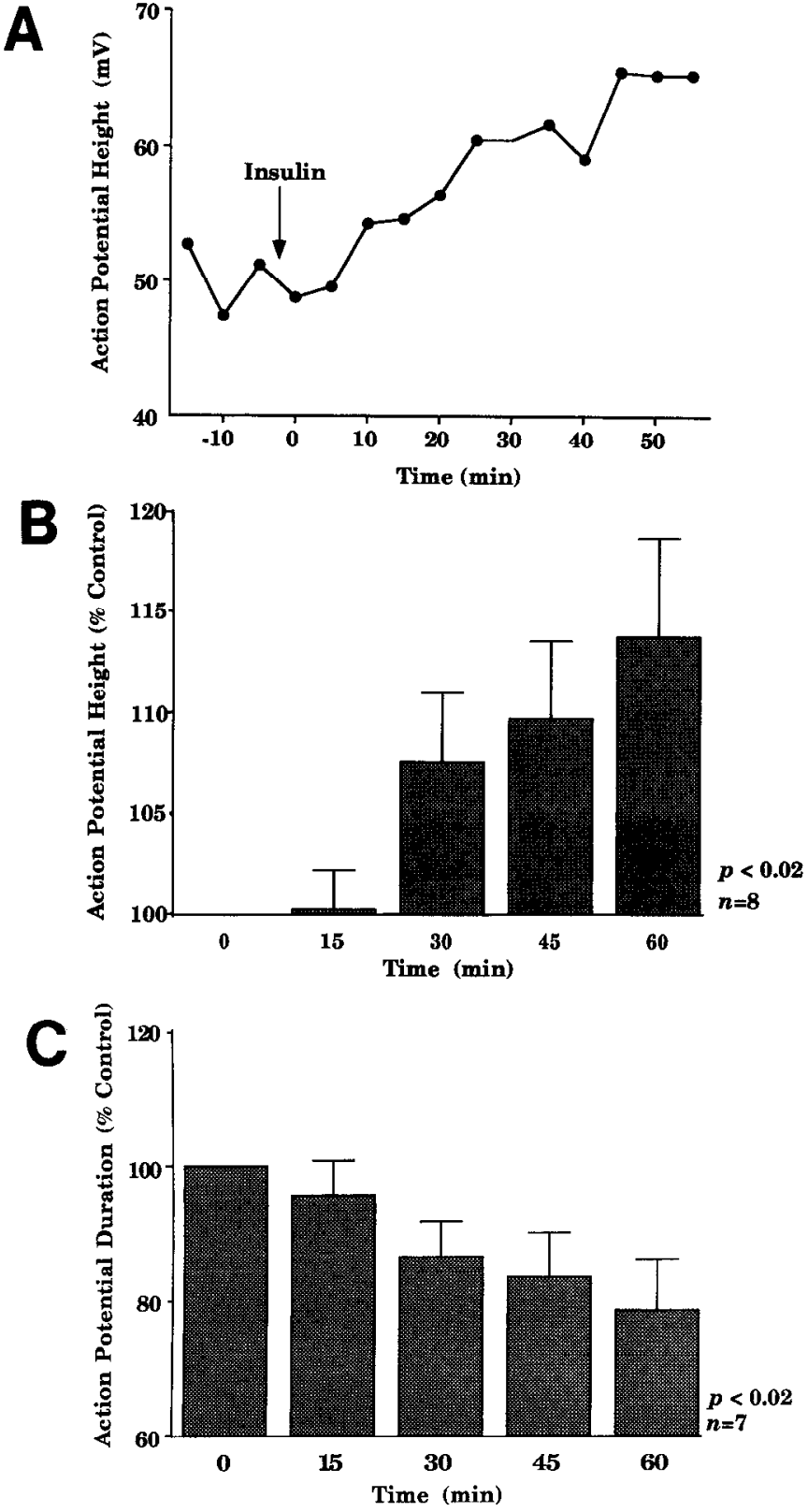

Figure 7. Insulin increases action potential amplitude and decreases action potential duration. $A$, The time course of the effect on action potential height in one bag cell neuron. Insulin was added just before $t=$ 0 (arrow). $B$, The mean action potential heights are plotted for eight neurons that were measured every $15 \mathrm{~min}$ over the course of $1 \mathrm{hr}$. Results are normalized to the mean values before adding insulin (before $t=0$ ). Neurons used in the analysis had similar morphologies and resting membrane potentials. $C$, Mean time course of the decrease in duration (expressed as percent of mean control) of action potentials from seven neurons. The results were obtained before $(t=0)$ and at the indicated times after adding insulin.

activators of protein kinase $\mathrm{C}$, and this enhancement can be blocked by preincubation with the Ser/Thr protein kinase inhibitor $\mathbf{H} 7$ (Conn et al., 1989). Previous work on bag cell neurons has shown that $\mathrm{H} 7$ alone is without effect on $\mathrm{Ba}^{2+}$ currents in untreated cells (Conn et al., 1989), and this finding was confirmed in the present study using isolated cells prepared from the same cluster (control peak Ba ${ }^{2+}$ current, $2.48 \pm 0.56 \mathrm{nA}$; current in $\mathrm{H} 7$, $2.80 \pm 0.94 ; p<0.77 ; n=4)$. When cells that had been treated with insulin were compared with cells treated with insulin in the presence of $100 \mu \mathrm{M} \mathrm{H} 7$, however, $\mathrm{H} 7$ was found to produce a $38 \%$ decrease in the insulin-enhanced $\mathrm{Ba}^{2+}$ currents $(p<0.01, n=6$; data not shown).

\section{Insulin increases a component of $\mathbf{K}^{+}$current}

One of the effects of insulin on the action potentials of bag cell neurons is to decrease their width. Because $\mathrm{K}^{+}$currents play an important role in the repolarization of action potentials, we tested the effect of insulin on outward currents recorded in ASW. In the cell shown in Figure $9 A$, insulin produced an increase in the amplitude of delayed outward currents evoked by stepping the membrane potential from $-40 \mathrm{mV}$ to potentials between -30 and $+30 \mathrm{mV}$. The currents were increased at all potentials, and the tail currents recorded at the end of the depolarization were also enhanced. The combined data from 19 neurons show that insulin produced a mean increase in delayed outward current of $17.4 \pm$ $5.3 \%(p<0.005$; Fig. 9D). This increase in outward current began 10-40 min after adding insulin. In contrast, the transient A-type $\mathrm{K}^{+}$currents, evoked by stepping the membrane potential to -40 $\mathrm{mV}$ from more negative potentials, were not affected by insulin treatment (Fig. 9B,D; peak outward current on stepping from -100 to $-40 \mathrm{mV}$ before insulin: $1.94 \pm 0.33 \mathrm{nA}$; after insulin: 1.97 $\pm 0.31 \mathrm{nA}$ ).

Previous work has shown that the outward current in isolated bag cell neurons, recorded in $\mathrm{Ca}^{2+}$-containing ASW and cvoked by depolarizations from holding potentials of $-40 \mathrm{mV}$, consists of a $\mathrm{Ca}^{2+}$-activated $\mathrm{K}^{+}$current and two components of voltagedependent $\mathrm{K}^{+}$current (Kaczmarek and Strumwasser, 1984; Strong and Kaczmarek, 1986; Quattrocki et al., 1994). Because insulin increases $\mathrm{Ca}^{2+}$ currents, an increase in outward current could be secondary to increased $\mathrm{Ca}^{2+}$ entry, reflecting enhanced activation of a $\mathrm{Ca}^{2+}$-activated $\mathrm{K}^{+}$current. To determine whether insulin has an effect on the voltage-dependent $\mathrm{K}^{+}$currents, we tested its effect on four neurons in the presence of $10 \mathrm{mM} \mathrm{CoCl}_{2}$, which eliminates the voltage-gated $\mathrm{Ca}^{2+}$ current in molluscan neurons (Kaczmarek and Strumwasser, 1984; Byerly and Hagiwara, 1988). Under these conditions, insulin increased the delayed $\mathrm{K}^{+}$current in all of the cells (mean increase, $32 \pm 8 \%, p<0.02$; Fig. $9 D$ ) as well as the amplitude of the outward tail currents (Fig. $9 C$ ). These experiments suggest that the enhancement of voltagedependent $\mathrm{K}^{+}$currents by insulin does not depend on the entry of $\mathrm{Ca}^{2+}$.

\section{DISCUSSION}

We have found that insulin receptors are highly expressed in the bag cell neurons of Aplysia. The binding of insulin to these receptors results in the autophosphorylation of the $\beta$ subunit on tyrosine residues and produces an increase in the amplitude of voltage-dependent $\mathrm{Ca}^{2+}$ and $\mathrm{K}^{+}$currents, leading to increased excitability of these cells. Neuronal processes surrounding the clusters of bag cell neurons are immunopositive for insulin-like peptides. These processes possibly originate from cells in the cerebral ganglia, which have been shown to contain an insulin-like activity (Stadtmauer et al., 1994). The actions of insulin on the bag cell neurons suggest that insulin may have a previously undescribed role as a neuromodulator or neurotransmitter. Because bag cell neurons function to initiate egg laying, it is possible that insulin regulates the triggering of egg laying and its associated behaviors. 

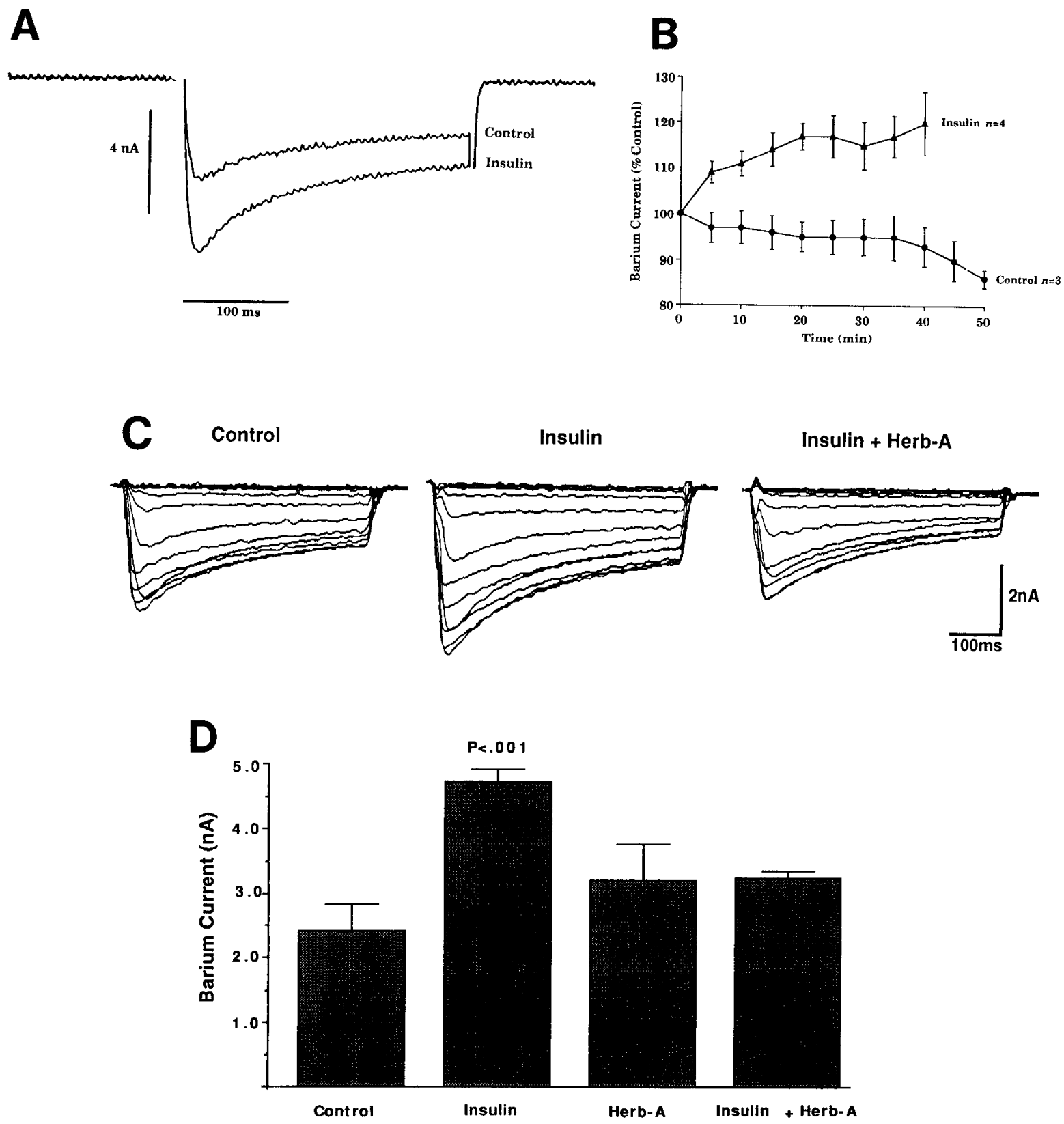

Figure 8. Insulin increases voltage-dependent inward current. $A, \mathrm{Ba}^{2+}$ currents evoked by a depolarizing step from -60 to $-10 \mathrm{mV}$ recorded from a bag cell neuron before (Control) and 30 min after the addition of $5 \mu \mathrm{M}$ Insulin. $B$, Plot of the mean amplitude of Ba ${ }^{2+}$ currents measured at 5 min intervals from four cells treated with Insulin and from three Control cells. The amplitude of the currents has been normalized to the mean pretreatment value for each cell $(t=0)$. Error bars indicate SEM. $C, \mathrm{Ba}^{2+}$ currents in response to a series of $500 \mathrm{msec}$ depolarizing voltage steps to potentials between -30 and $+25 \mathrm{mV}$ in $5 \mathrm{mV}$ increments. Holding potential was $-60 \mathrm{mV}$. Traces from three different cells from the same bag cell cluster are shown: an untreated bag cell neuron (Control); a cell treated with $5 \mu \mathrm{M}$ insulin for 90 min (Insulin); and a cell treated with insulin for 90 min in the presence of $1.7 \mu \mathrm{M}$ herbimycin A (Insulin + Herb-A). $D$, The histogram shows the mean peak $\mathrm{Ba}^{2+}$ current \pm SEM for four groups of cells from the same cluster: Control, Insulin alone, herbimycin A alone (Herb-A), and herbimycin A with insulin (Insulin + Herb-A).

\section{The Aplysia insulin receptor}

Comparison of the deduced amino acid sequence of the cDNA clone $\mathrm{Apl}$-IR with other tyrosine kinases reveals domains characteristic of the somatomedin receptor family (Hanks et al., 1988). The Aplysia $\alpha$ subunit sequence contains a Cys-rich domain present in all oller insulin-like receptors, which is believed to be the insulin binding site (Rosen, 1987). Conservation of the total extracellular insulin-binding $\alpha$ domain sequence is poor, but this is to be expected for the $\alpha$ subunit across phylogeny. Binding and functional studies suggest that $A p l$-IR functions as a receptor. Immunocytochemistry in bag cell neurons using the human antipeptide insulin-binding antibody shows strong immunoreactivity both in intact isolated abdominal ganglia and in dissociated neurons in culture. As reported for some other cells (Joose et al., 1993), staining is not localized solely to the plasma membrane but is also present in cytoplasm, possibly as a result of internalization of plasma membrane receptors. The $A p l$-IR is most abundant in bag cell neurons, a group of cells that function to initiate egg 


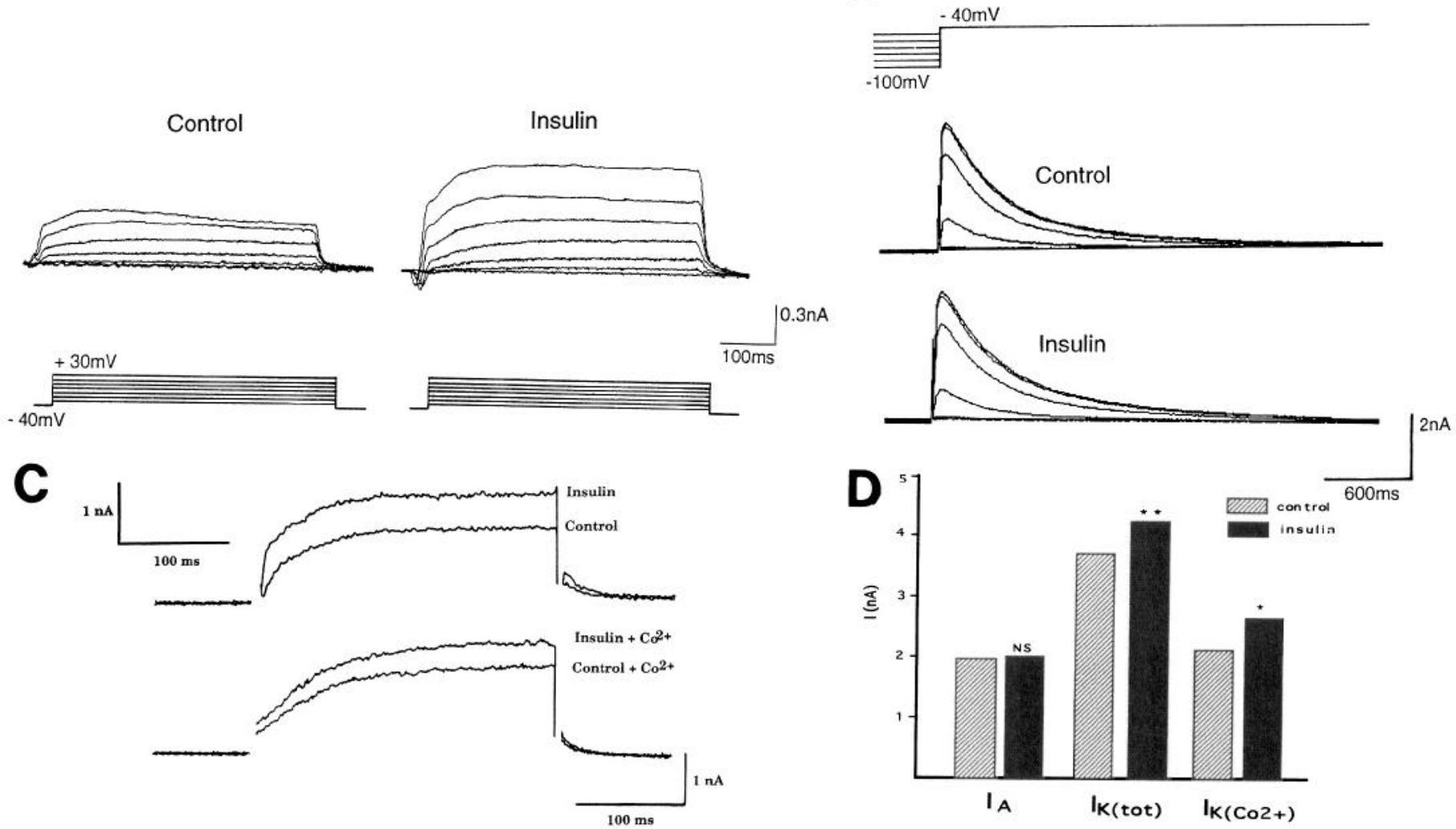

Figure 9. Insulin increases delayed $\mathrm{K}^{+}$current. $A$, Insulin-induced increase in $\mathrm{K}^{+}$current of a single bag cell neuron recorded in normal ASW. Currents were evoked by voltage steps from $-40 \mathrm{mV}$ to test potentials between -30 and $+30 \mathrm{mV}$ in $10 \mathrm{mV}$ increments and were recorded before (Control) and $30 \mathrm{~min}$ after Insulin treatment. The typical increase in the inward current in response to insulin can also be seen in these traces before the onset of the delayed outward currents. B, Lack of effect of insulin on A-current. A series of traces was obtained by holding at $-40 \mathrm{mV}$ and then giving a series of hyperpolarizing pulses from -100 to $-50 \mathrm{mV}$. The two sets of traces were obtained before and $20 \mathrm{~min}$ after insulin treatment. $C$, Insulin increases delayed $\mathrm{K}^{+}$current in the presence of external $\mathrm{Co}^{2+}$ : superimposed currents before and after application of insulin in normal ASW (top traces); superimposed currents before and after application of insulin in ASW containing $10 \mathrm{mM} \mathrm{CoCl}_{2}$ (bottom traces). Currents were evoked by voltage steps from -40 to 0 $\mathrm{mV}$. D, Histograms of mean control currents and currents after administration of $5 \mu \mathrm{M}$ insulin. Data are shown for the A-current, measured by stepping the potential from -100 to $-40 \mathrm{mV}$ (see $B ; n=9$ ). For the total delayed $\mathrm{K}^{+}$current $\left(I_{K(t o t)}\right)$ and for the delayed $\mathrm{K}^{+}$current in the presence of Co ${ }^{2+}$ $\left(\mathrm{I}_{\mathrm{K}(\mathrm{C} 22+)}\right)$, membrane potential was stepped from -40 to $+30 \mathrm{mV}$ (see $A$ and $C ; n=19$ for $I_{\mathrm{K}(\text { tot })} ; n=4$ for $\left.I_{\mathrm{K}(\mathrm{Co2}+)}\right) . N S$, Not significant; ${ }^{*} p<0.02$, ${ }_{* *}^{*}(\mathrm{CO2}+), 0.005$.

laying and its accompanying reproductive behaviors (Scheller et al., 1983; Conn and Kaczmarek, 1989). By using sensitive PCR, we found that this insulin-like receptor transcript is also present in cells elsewhere in the nervous system, including large neurons in the abdominal ganglion (D. H. Solomon and J. H. Schwartz, unpublished observations).

We used vertebrate insulin to stimulate the kinase activity of the bag cell neuron insulin receptor. In common with the mammalian receptor, insulin binding appears to result in the autophosphorylation of the $\beta$ subunit of the receptor on tyrosine residues and this phosphorylation is inhibited by the tyrosine kinase inhibitor herbimycin A. As with the Drosophila receptor (Garofalo and Rosen, 1988), we found that higher concentrations of the heterologous ligand are needed than for a vertebrate receptor. The requirement for a higher concentration suggests that mammalian insulin is a poor homolog of the endogenous molluscan peptides. It is not surprising that the binding constant of $\left[{ }^{125} \mathrm{I}\right]$ porcine insulin to Aplysia tissucs is about an order of magnitude greater than for placental membranes; Petruzelli et al. (1985) also found that $\left[{ }^{125} \mathrm{I}\right]$ porcine insulin binds to Drosophila membranes with a $K_{\mathrm{d}}$ of $120 \mathrm{~nm}$.

\section{Mechanisms of ion channel modulation in the bag cell neurons}

Exposure of isolated bag cell neurons to bovine insulin produces an increase in the amplitude of action potentials. This increase is accompanied by an enhancement of voltage-dependent $\mathrm{Ca}^{2+}$ and $\mathrm{K}^{+}$currents that occurs over $15-30 \mathrm{~min}$. This time course suggests that insulin acts as a neuromodulator or neurotransmitter rather than as a trophic factor. Effects of growth factors on ion currents in neuroendocrine cells have been described previously, but these effects typically occur over several days and are believed to involve regulation of expression of the ion channels in the cell membrane (Garber et al., 1989).

The effects of insulin on $\mathrm{Ca}^{2+}$ current are blocked by pretreatment of the cells with herbimycin A, an agent that prevents autophosphorylation of the bag cell insulin receptor on tyrosine residues. Activation of the insulin receptor may be followed by the recruitment of other second messenger pathways. For example, changes in the activity of the CAMP-dependent protein kinase and of protein kinase $\mathrm{C}$ are known to affect bag cell neuron $\mathrm{K}^{+}$and $\mathrm{Ca}^{2+}$ currents, respectively (DeRiemer et al., 1985; Strong et al., 1987; Knox and Kaczmarek, 1992; Loechner and Kaczmarek, 
1994). Exposure to insulin results in the activation of protein kinase $\mathrm{C}$ in bag cell neurons (W. S. Sossin, C.-S. Chen, and Alex Toker, unpublished data), and our results suggest that the effects of insulin on $\mathrm{Ca}^{2+}$ currents can be blocked by $\mathrm{H} 7$, an inhibitor of protein kinase $\mathrm{C}$ in bag cell neurons (Conn et al., 1989). Thus, it is possible that the enhancement of $\mathrm{Ca}^{2+}$ current by insulin results from the recruitment of the protein kinase $\mathrm{C}$ regulated $\mathrm{Ca}^{2+}$ channels that have been described in these cells (Strong et al., 1987), although this hypothesis has yet to be tested directly.

Other signal transduction pathways linking growth factor receptors to ion channel functions also exist (Palovcik et al., 1984; Sakaguchi and Bray, 1987; Shapiro et al., 1991; Selinfreund and Blair, 1994). Regulation of $\mathrm{K}^{+}$channels by EGF, acting through both inositol trisphosphate and protein kinase $\mathrm{C}$, has been reported for cloned ion channels expressed in Xenopus oocytes (Timpe and Fantl, 1994). EGF may also stimulate phospholipase $\mathrm{A}_{2}$ activation with resultant modulation of $\mathrm{Ca}^{2+}$ channels (Peppelenbosch et al., 1992). In addition, it is not yet known whether pathways such as the mitogen-activated protein kinase cascade (Boulton et al., 1991) are able to modulate excitability. One indirect pathway of insulin action that has been studied in Aplysia (Shapiro et al., 1991) and in liver, adipocytes, and erythroleukemic cells (Misek and Saltiel, 1992, 1994; Lazar et al., 1994) is the formation of inositol phosphate glycan (IPG). When injected into Aplysia L14 neurons, IPG mimics application of insulin.

\section{Aplysia insulin-like peptides}

The source of the endogenous insulin-like peptide that normally acts on the bag cell neurons has not yet been determined. Two possibilities exist. Insulin-like peptides may act as hormones released from a glandular source or may act as neuropeptides released directly onto bag cell neurons from presynaptic nerve terminals. In Lymnaea, there are four gene families encoding insulin-like peptides, MIP I, II, III, and V (Smit et al., 1988, 1991; Meester et al., 1992). In situ hybridization in Lymnaea shows that the MIP I family is expressed only in specific cells of the cerebral ganglion that regulate reproduction (Smit et al., 1988), whereas the MIP II and MIP III families are expressed in other cells in the nervous system. Because the Aplysia bag cell neuron insulin receptor is encoded by a single gene, if there are multiple insulinlike peptides in Aplysia, they may bind to the receptor with different affinities and may be released from distinct sites, acting either as hormones or as peptide transmitters.

In addition to its actions on the bag cell neurons, insulin has actions on other identified Aplysia neurons. Shapiro et al. (1991) showed that vertebrate insulin hyperpolarizes L14 cells-motor neurons for inking. Because both L14 and bag cell neurons are involved in complex behaviors, endogenous insulin-like peptides may integrate these behaviors. Insulin suppresses the firing of L14 cclls, making it morc difficult for the animal to ink. If insulin secretion rises after feeding, as in vertebrates (see Schwartz et al., 1992), this would serve to suppress inking during feeding, a discordant behavior. Through their actions on bag cell neurons, insulin-like peptides may regulate egg laying (Conn and Kaczmarek, 1989) and may contribute to the initiation of mating behavior after feeding (Ziv et al., 1989).

\section{REFERENCES}

Baskin DG, Figlewicz DP, Woods SC, Porte Jr D, Dorsa DM (1987) Insulin in the brain. Annu Rev Physiol 49:335-347.

Boyd FT, Clarke DW, Mather TF, Raizada MK (1985) Insulin receptors and insulin modulation of norepinephrine uptake in neuronal cultures from rat brain. J Biol Chem 260:15880-15884.
Boulton TG, Nye SH, Robbins DJ, Ip NY, Radziejewska E, Morgenbesser SD, DePinho RA, Panayotatos N, Cobb MH, Yancopoulos GD (1991) ERKs: a family of protein-serine/threonine kinases that are activated and tyrosine phosphorylated in response to insulin and NGF. Cell 65:663-675.

Bradford MM (1976) A rapid and sensitive method for the quantitation of microgram quantities of protein utilizing the principle of protein-dye binding. Anal Biochem 72:248-254.

Byerly L, Hagiwara S (1988) Calcium channel diversity. In: Calcium and ion channel modulation (Grinnell $\mathrm{AD}$, Armstrong D, Jackson MB, eds), pp 3-18. New York: Plenum.

Cantley LC, Auger KR, Carpenter C, Duckworth B, Graziani A, Kapeller $\mathrm{K}$, Soltoff $\mathrm{S}$ (1991) Oncogenes and signal transduction. Cell 64:281-302.

Chin GJ, Shapiro E, Vogel SS, Schwartz JH (1989) Aplysia synaptosomes. I. Preparation and biochemical and morphological characterization of subcellular membrane fractions. J Neurosci 9:38-48.

Chirgwin JJ, Przbyla AE, MacDonald RJ, Rutter WJ (1979) Isolation of biologically active ribonucleic acid from sources enriched in ribonuclease. Biochemistry 18:5294-5298.

Chiu AY, Strumwasser F (1981) An immunohistochenical study of the neuropeptidergic bag cells of Aplysia. J Neurosci 1:812-826.

Conn PJ, Kaczmarek LK (1989) The bag cell neurons of Aplysia. Mol Neurobiol 3:237-273.

Conn PJ, Strong JA, Azhderian EM, Nairn AC, Greengard P, Kaczmarek LK (1989) Protein kinase inhibitors selectively block phorbol ester- or forskolin-induced changes in excitability of Aplysia neurons. J Neurosci 9:473-479.

Cuatrecasas $P$ (1972) Isolation of the insulin receptor of liver and fat-cell membranes (detergent-solubilized-( $\left.{ }^{125} \mathrm{I}\right)$ insulin-polyethylene glycol precipitation-sephadex). Proc Natl Acad Sci USA 69:318.

Czech MP, Lynn WS (1973) The plasma membrane of isolated fat cells. J Biol Chem 248:5081-5088.

DeRiemer SA, Strong JA, Albert KA, Greengard P, Kaczmarek LK (1985) Enhancement of calcium current in Aplysia neurons by phorbol ester and protein kinase C. Nature 313:313-316.

Eisenstadt M, Goldman JE, Kandel ER, Koike H, Koester J, Schwartz JH (1973) Intrasomatic injection of radioactive precursors for studying transmitter synthesis in identified neurons of Aplysia californica. Proc Natl $\Lambda$ cad Sci US $\Lambda$ 70:3371-3375.

Garber SS, Hoshi T, Aldrich RW (1989) Regulation of ionic currents in pheochromocytoma cells by nerve growth factor and dexamethasone. J Neurosci 9:3976-3987.

Garofalo RS, Rosen OM (1988) Tissue localization of Drosophila melanogaster insulin receptor transcripts during development. Mol Cell Biol 8:1638-1647.

Goldberg DJ, Burmeister DW (1992) Microtubule-based filopodium-like protrusions form after axotomy. I Neurosci 12:4800-4807.

Grant SG, O'Dell TJ, Karl KA, Stein PL, Soriano P, Kandel ER (1992) Impaired long-term potentiation, spatial learning, and hippocampal devclopmcnt in fyn mutant mice. Science 258:1903-1910.

Hanks SK, Quinn AM, Hunter T (1988) The protein kinase family: conserved features and deduced phylogeny of the catalytic domains. Science 241:42-52.

Harlow E, Lane D (1988) Antibodies: a laboratory manual. Cold Spring Harbor, NY: Cold Spring Harbor Laboratory.

Havrankova J, Roth J, Brownstein M (1978) Insulin receptors are widely distributed in the central nervous system of the rat. Nature 272:827-829

Huang X-Y, Morielli AD, Peralta EG (1993) Tyrosine kinase-dependent suppression of a potassium channel by the $\mathrm{G}$ protein-coupled $\mathrm{ml}$ muscarinic acetylcholine receptor. Cell 75:1145-1156.

Huganir RL, Greengard P (1990) Regulation of neurotransmitter receptor desensitization by protein phosphorylation. Neuron 5:555-567.

Joose M, Biosca JA, Trujillo R, Itartee E (1993) Characterization of the hepatic insulin receptor undergoing internalization through clathrincoated vesicles and endosomes. FEBS Lett 334:286-288.

Kaczmarek LK, Strumwasser F (1981) The expression of a long-lasting afterdischarge by Aplysia bag cell neurons. J Neurosci 1:626-634.

Kaczmarek LK, Strumwasser F (1984) A voltage-clamp analysis of currents underlying cyclic AMP-induced membrane modulation in isolated peptidergic neurons of Aplysia. J Neurophysiol 52:340-349.

Knox RJ, Kaczmarek LK (1992) Regulation of neuronal ion channels by protein kinase C. In: Protein kinase $\mathrm{C}$ : current concepts and future 
perspectives (Lester DS, Epand RM, eds), pp 274-296. New York: Ellis Horwood.

Kozak M (1987) An analysis of 5'-noncoding sequences from 699 vertebrate messenger RNAs. Nucleic Acids Res 15:8125-8148.

Lai C, Lemke G (1991) An extended family of protein-tyrosine kinase genes differentially expressed in the vertebrate nervous system. Neuron 6:691-704.

Lazar DF, Knez JJ, Medof ME, Cuatrecasas P, Saltiel AR (1994) Stimulation of glycogen synthesis by insulin in human erythroleukemia cells requires the synthesis of glycosyl-phosphatidylinositol. Biochemistry 91:9665-9669.

Lee CC, Caskey CT (1990) cDNA cloning using degenerate primers. In: PCR protocols (Innis MA, Gelfand DH, Sninsky JJ, White TJ, eds), pp 46-53. San Diego: Academic.

Loechner KJ, Kaczmarek LK (1994) Autoactive peptides act at three distinct receptors to depolarize the bag cell neurons of Aplysia. J Neurophysiol 71:195-203.

Maness PF, Cox ME (1992) Protein tyrosine kinases in nervous system development. Semin Cell Biol 3:117-126.

Meester I, Ramkema MD, van Minnen J, Boer HH (1992) Differential expression of four genes encoding molluscan insulin-related peptides in the central nervous system of the pond snail Lymnaea stagnalis. Cell Tissue Res 269:183-188.

Misek DE, Saltiel AR (1992) An inositol phosphate glycan derived from a Trypanosoma brucei glycosyl phosphatidylinositol mimics some of the metabolic actions of insulin. J Biol Chem 267:16266-16373.

Misek DE, Saltiel AR (1994) An inositol phosphate glycan derived from a Trypanosoma brucei glycosyl phosphatidylinositol promotes protein dephosphorylation in rat epididymal adipocytes. Endocrinology 135:1869-1876.

O'Dell TJ, Kandel ER, Grant SG (1991) Long-term potentiation in the hippocampus is blocked by tyrosine kinase inhibitors. Nature 353:558-560.

Palovcik RA, Phillips MI, Kappy MS, Raizada MK (1984) Insulin inhibits pyramidal neurons in hippocampal slices. Brain Res 309:187-191.

Peppelenbosch MP, Tertoolen LGJ, den Hertog J, de Laat SW (1992) Epidermal growth factor activates calcium channels by phospholipase A2/ 5-lipoxygenase-mediated leukotriene C4 production. Cell 69:295-303.

Petruzelli LM, Ganguly S, Smith CJ, Cobb MH, Rubin CS, Rosen OM (1982) Insulin activates a tyrosine-specific protein kinase in extracts of 3T3-L1 adipocytes and human placenta. Proc Natl Acad Sci USA 79:6792-6796.

Petruzelli LM, Herrera R, Garcia R, Rosen OM (1985) The Drosophila insulin receptor. In: Cancer cells: growth factors and transformation, Vol 3 (Ferimisco J, Ozanne B, Stiles C, eds), pp 115-121. Cold Spring Harbor, NY: Cold Spring Harbor Laboratory.

Quattrocki EA, Marshall J, Kaczmarek LK (1994) A Shab potassium channel contributes to action potential broadening in peptidergic neurons. Neuron 12:73-86.

Rosen OM (1987) After insulin binds. Science 237:1452-1458.

Sakaguchi T, Bray GA (1987) Intrahypothalamic injection of insulin decreases firing rate of sympathetic nerves. Proc Natl Acad Sci USA 84:2012-2014.

Sambrook J, Fritsch EF, Maniatis T (1989) Molecular cloning: a laboratory manual, 2nd Ed. Cold Spring Harbor, NY: Cold Spring Harbor Laboratory.

Scheller RH, Jackson JF, McAllister LB, Rothman BS, Mayeri E, Axel R (1983) A single gene encodes multiple neuropeptides mediating a stereotyped behavior. Cell 32:7-22.

Schlessinger J, Ullrich A (1992) Growth factor signaling by receptor tyrosine kinases. Neuron 9:383-391.

Schwartz MW, Sipols AJ, Marks JL, Sanacora G, White JD, Scheurink A, Kahn SE, Baskin DG, Woods SC, Figlewicz DP, Porte Jr D (1992) Inhibition of hypothalamic neuropeptide $Y$ gene expression by insulin. Endocrinology 130:3608-3616.
Schweitzer JB, Smith RM, Jarett L (1980) Differences in organizational structure of insulin receptors on rat adipocyte and liver plasma membrane: role of disulfide bonds. Proc Natl Acad Sci USA 77:4692-4696. Selinfreund RH, Blair LA (1994) Insulin-like growth factor-I induces a rapid increase in calcium currents and spontaneous membrane activity in clonal pituitary cells. Mol Pharmacol 45:1215-1220.

Shapiro E, Brown SD, Saltiel AR, Schwartz JH (1991) Short-term action of insulin on Aplysia neurons: generation of a possible novel modulator of ion channels. J Neurobiol 22:55-62.

Smit AB, Vreugdenhil E, Ebberink RHM, Geraerts WPM, Klootwijk J, Joosse J (1988) Growth-controlling molluscan neurons produce the precursor of an insulin-related peptide. Nature 331:535-538.

Smit AB, van Marle A, van Elk R, Geraerts WPM, van Heerikhuizen $H$, Joosse J (1991) The organization, expression, and evolution of the insulin-related gene family in the mollusc Lymnaea stagnalis. In: Molluscan neurobiology (Kits KS, Boer HH, Joosse J, eds), pp 316321. Amsterdam: North-Holland.

Southern E (1975) Detection of specific sequences among DNA fragments separated by gel electrophoresis. J Mol Biol 98:503-517.

Stadtmauer L, Rosen OM (1983) Phosphorylation of exogenous substrates by the insulin receptor-associated protein kinase. J Biol Chem 258:6682-6685.

Stadtmauer L, Koester J, McKay NM, Solomon DH, Schwartz JH (1994) Evidence for insulin-like peptides in Aplysia and possible localization in the cerebral ganglia. Soc Neurosci Abstr 20:1281.

Steiner DF, Chan SJ, Welsh JM, Kwok SCM (1985) Structure and evolution of the insulin gene. Annu Rev Genet 19:463-484.

Strong JA, Kaczmarek LK (1986) Multiple components of delayed potassium current in peptidergic neurons of Aplysia: modulation by an activator of adenylate cyclase. J Neurosci 6:814-822.

Strong JA, Fox AP, Tsien RW, Kaczmarek LK (1987) Stimulation of protein kinase $\mathrm{C}$ recruits covert calcium channels in Aplysia bag cell neurons. Nature 325:714-717.

Thorpe A, Duve H (1984) Insulin and glucagon-like peptides in insects and molluscs. Mol Physiol 5:235-260.

Timpe LC, Fantl WJ (1994) Modulation of a voltage-activated potassium channel by peptide growth factor receptors. J Neurosci 14:1195-1201.

Uehara Y, Hori M, Takeuchi T, Umezawa H (1986) Phenotypic change from transformed to normal induced by benzoquinonoid ansamycins accompanies inactivation of $\mathrm{p} 60^{\mathrm{src}}$ in rat kidney cells infected with rous sarcoma virus. Mol Cell Biol 6:2198.

Ullrich A, Bell JR, Chen EY, Herrera R, Petruzelli LM, Dull TJ, Gray A, Coussens L, Liao YC, Tsubokawa M, Mason A, Seburg PH, Grunfeld C, Rosen OM, Ramachandran J (1985) Human insulin receptor and its relationship to the tyrosine kinase family of oncogenes. Nature 313:756-761.

Uvnas-Wallenstein K (1981) Peptides in metabolic autonomic nerves. Diabetologia 20:337-312.

Van Minnen J, Schallig H (1990) Demonstration of insulin-related substances in the central nervous systems of pulmonates and Aplysia californica. Cell Tissue Res 260:381-386.

Wang YT, Salter MW (1994) Regulation of NMDA receptors by tyrosine kinases and phosphatases. Nature 369:233-235.

Wilson GF, Kaczmarek LK (1993) Mode switching of a voltage-gated cation channel is mediated by a protein kinase A-regulated tyrosine phosphatase. Nature 366:433 438.

Wolinsky EJ, Patterson PH, Willard AL (1985) Insulin promotes electrical coupling between cultured sympathetic neurons. J Neurosci 5:1675-1679.

Ziv I, Benni M, Markovich S, Susswein AJ (1989) Motivational control of sexual behavior in Aplysia fasciata: sequencing and modulation by sexual deprivation and by addition of partners. Behav Neural Biol 52:180-193. 